Review

\title{
Bisphenol A and Its Analogues Deteriorate the Hormones Physiological Function of the Male Reproductive System: A Mini-Review
}

\author{
Asma' 'Afifah Shamhari ${ }^{1}$, Zariyantey Abd Hamid ${ }^{1}$, Siti Balkis Budin ${ }^{1}$, Nurul Jehan Shamsudin ${ }^{2}$ \\ and Izatus Shima Taib ${ }^{1, * \mathbb{D}}$ \\ 1 Centre for Diagnostic, Therapeutic and Investigative Studies, Faculty of Health Sciences, \\ Universiti Kebangsaan Malaysia, Jalan Raja Muda Abdul Aziz, Kuala Lumpur 50300, Malaysia; \\ p109998@siswa.ukm.edu.my (A.'A.S.); zyantey@ukm.edu.my (Z.A.H.); balkis@ukm.edu.my (S.B.B.) \\ 2 Centre for Toxicology and Health Risk Research, Faculty of Health Sciences, Universiti Kebangsaan Malaysia, \\ Jalan Raja Muda Abdul Aziz, Kuala Lumpur 50300, Malaysia; nuruljehan@ukm.edu.my \\ * Correspondence: izatusshima@ukm.edu.my; Tel.: +60-3-9289-7608
}

Citation: Shamhari, A.'.; Abd Hamid, Z.; Budin, S.B.; Shamsudin, N.J.; Taib, I.S. Bisphenol A and Its Analogues Deteriorate the Hormones Physiological Function of the Male Reproductive System: A Mini-Review. Biomedicines 2021, 9, 1744. https:// doi.org/10.3390/biomedicines9111744

Academic Editor: Shaker A. Mousa

Received: 18 October 2021

Accepted: 20 November 2021

Published: 22 November 2021

Publisher's Note: MDPI stays neutral with regard to jurisdictional claims in published maps and institutional affiliations.

Copyright: (c) 2021 by the authors. Licensee MDPI, Basel, Switzerland. This article is an open access article distributed under the terms and conditions of the Creative Commons Attribution (CC BY) license (https:// creativecommons.org/licenses/by/ $4.0 /)$.
Abstract: BPA is identified as an endocrine-disrupting chemical that deteriorates the physiological function of the hormones of the male reproductive system. Bisphenol F (BPF), bisphenol S (BPS), and bisphenol AF (BPAF) are actively explored as substitutes for BPA and are known as BPA analogues in most manufacturing industries. These analogues may demonstrate the same adverse effects as BPA on the male reproductive system; however, toxicological data explaining the male reproductive hormones' physiological functions are still limited. Hence, this mini-review discusses the effects of BPA and its analogues on the physiological functions of hormones in the male reproductive system, focusing on the hypothalamus-pituitary-gonad (HPG) axis, steroidogenesis, and spermatogenesis outcomes. The BPA analogues mainly show a similar negative effect on the hormones' physiological functions, proven by alterations in the HPG axis and steroidogenesis via activation of the aromatase activity and reduction of spermatogenesis outcomes when compared to BPA in in vitro and in vivo studies. Human biomonitoring studies also provide significant adverse effects on the physiological functions of hormones in the male reproductive system. In conclusion, BPA and its analogues deteriorate the physiological functions of hormones in the male reproductive system as per in vitro, in vivo, and human biomonitoring studies.

Keywords: aromatase; bisphenol F; bisphenol AF; bisphenol S; HPG axis; steroidogenesis; spermatogenesis

\section{Introduction}

Bisphenol A (BPA) (4,4'-dihydroxy-2,2-diphenyl propane) is an organic synthetic monomer, reported to be one of the most produced chemicals in the world. About 7 million tonnes of BPA was produced in 2013, and this figure is estimated to be growing annually [1,2]. BPA was initially synthesized by the scientist Aleksandr Pavlovich Dianin in 1891. BPA's resistance to high temperatures, shatterproof nature, and electrical insulation capability has led to this chemical being predominantly used in most epoxy resin and polycarbonate plastic industries [3-5]. Epoxy resin is a precursor chemical of any product that requires resilience and high durability, such as a dental sealant, amalgams, tanks, sports equipment, roads, structural adhesives, and coating materials in cans [6-9]. Polycarbonate plastic is also used as packaging or as containers for many daily consumable products, such as vegetables, fruits, milk bottles, plastic bags, and food and beverage containers. Furthermore, these polycarbonate plastics can also be involved in the packaging of personal care products such as shampoo, body wash, and cosmetics [7-13].

The extensive use of BPA in various industries has resulted in environmental pollution: BPA has reportedly been found in rivers, lakes, soils, sediments, home dust, and air [14-18]. 
The most alarming concern is that BPA has also been detected in human biological samples, such as in the blood, urine, sweat, breast milk, and in the umbilical cord [19-21]. BPA in human biological samples is expected, as it can be found in their food and drinking water, indicating that the most common source of BPA exposure in humans is oral [22-25]. Furthermore, BPA can also be exposed to humans via the dermis, which mostly occurs when someone is in indirect contact with thermal receipt paper. Humans may also be exposed to BPA through inhalation [26-29]. Recently, the negative impact of BPA has been widely reported by scientists and has been identified as a well-known endocrine-disrupting chemical (EDC) [30-32]. Previous studies have reported that exposure to BPA causes many diseases, such as tumours, cardiovascular diseases, neurodegenerative diseases, metabolic diseases, such as diabetes mellitus, autoimmune diseases, and male and female infertility, and can disturb the development of children, babies, and foetuses [29,33-38]. BPA increases the risk of transgenerational toxicity effects in the offspring, proven by an increase in epigenetic markers such as H3K9Ac and H3K27Ac in the spermatozoa due to parental BPA exposure $[39,40]$.

The extensive adverse effects of BPA on human health have raised alarming awareness in society. Therefore, this chemical is being replaced with its analogues. Among the commonly used BPA analogues are bisphenol F (BPF), bisphenol S (BPS), and bisphenol AF (BPAF) [18,41-44]. These analogues share the same basic structure as BPA, where the two benzene rings are attached either with the short carbon or with other chemical chains $[45,46]$. However, these BPA analogues did not undergo proper toxicity evaluation testing before being used in the industry [47]. In 2015, the Environmental Protection Agency (EPA) reported a negative impact of BPA analogues on the aquatic system, environment, and human health [48]. Like BPA, its analogues also result in carcinogenicity, genotoxicity, neurotoxicity, reproductive toxicity, and developmental disorders [48]. Moreover, these analogues are also being categorized as EDCs.

Evidence showing that BPA and its analogues cause male infertility is growing. The most common mechanisms involved in toxicant-induced male infertility are oxidative stress and reproductive hormonal imbalance [49,50]. BPA and its analogues are also reported to exert oxidative stress in the plasma, testis, and sperm, resulting in spermatogenesis disturbance [51,52]. This disturbance leads to a reduction in sperm quality and testicular abnormalities, as shown by Leydig cell (LC), Sertoli cell (SC), and germ cell dysfunction [53]. $\mathrm{BPA}$ and its analogues also exhibited endocrine-disrupting activities in the male reproductive system, shown by the disturbance in the hypothalamus-pituitary-gonad (HPG) axis and steroidogenesis [54-56]. BPF, BPS, and BPAF share a property with oestradiol (E2), that is, these analogues possess the ability to activate the oestrogenic pathway in the human body system $[57,58]$. Their capability to mimic oestrogen-like properties causes a deterioration in the physiological function of the male reproductive system. Like other toxicants, BPA and its analogues display their affinity to bind to the oestrogen receptor (ER), such as $\mathrm{ER} \alpha, \mathrm{ER} \beta$, and oestrogen-related receptor gamma (ERR- $\gamma$ ) [56,59-62]. Furthermore, these chemicals also have the ability to disturb gene expression, such as Kiss1 and CYP19A1, which are involved in the HPG axis and steroidogenesis, respectively [63]. Recently, the effects of BPA and its analogues on these three significant pathways, in the form of the HPG axis [56,59,62,64-77], steroidogenesis [55,56,59,64-70,74-79], and spermatogenesis outcomes [64-70,75-77,80-85], have been well reported. To the best of our knowledge, the link between these three pathways in the exposures of BPA and its analogue is limited. Hence, this review was performed to connect the HPG axis, testicular steroidogenesis, and spermatogenesis outcomes after exposure to BPA and its analogues, leading to male reproductive toxicity

\section{Bisphenols and Hypothalamus-Pituitary-Gonadal Axis in Male Reproductive System}

The hypothalamus-pituitary axis is the main centre regulating endocrine hormone production in the human body, including the male reproductive system [2]. The hypothalamus releases the hormones responsible for stimulating the neuroendocrine activity of the 
pituitary glands, either in the anterior or posterior gland. One of the neuroendocrine activities regulated by the anterior pituitary gland is the HPG axis [3]. The HPG axis encounters three levels of hormone production: the hypothalamus releases the gonadotropin-releasing hormone $(\mathrm{GnRH})$, the anterior pituitary gland secretes the follicle-stimulating hormone (FSH) and luteinizing hormone (LH), and the testis, specifically the LC, synthesises testosterone. $\mathrm{GnRH}$, which is released from the hypothalamus, stimulates the anterior pituitary gland to release FSH and LH. Both hormones act on the testes to release target hormones, such as testosterone, oestrogen, progesterone, and inhibin. The primary purpose of this mechanism is to achieve homeostasis balance and modulate the positive and negative feedback of hormone regulation $[4,5]$. GnRH, LH, and FSH secretion are controlled by the neuropeptide kisspeptin (KiSS1), which is regulated by gene kiss1 [6-8]. Generally, the kiSS1 and G protein-coupled receptor 54 (GPR54) complex are involved in HPG axis feedback regulations [86]. KiSS1 binds to GPR54, also known as the kiss1 receptor, to form a Kiss1/GPR54 complex. This complex regulates the neuroendocrine reproductive axis by targeting the GnRH neuron to stimulate GnRH release [87]. Subsequently, GnRH stimulates neuron transmission at the anterior pituitary gland to induce the secretion of gonadotropic hormones, specifically LH and FSH. Furthermore, ER $\alpha$ also plays a significant role in regulating reproductive and sexual behaviour $[88,89]$. Once E2 binds to ER $\alpha$ in the hypothalamus, it suppresses GnRH secretion [90].

Several experimental studies revealed that BPA and its analogues, such as BPF, BPS, and BPAF, disturbed the HPG axis via KiSS1 and ER $\alpha$ by targeting mRNA gene expression. However, BPA and its analogues have either direct or indirect effects and are still controversial. Previous studies have reported that laboratory animals, such as rats and zebrafish, exposed to BPA showed an increase in Kiss1 mRNA expression in the brain [62,71-73]. Exposure to BPA at a dose of $50 \mu \mathrm{g} / \mathrm{kg} / \mathrm{bw}$ via drinking water caused an increase in Kiss 1 mRNA expression [71]. The same findings were also recorded in the offspring and pups of rats and the transgenic embryo of zebrafish [62,72,73]. Exposure of zebrafish embryos to $1000 \mu \mathrm{g} / \mathrm{L}$ of BPA and BPS at $120 \mathrm{~h}$ post-fertilization (hpf) revealed an increased expression of the Kiss1 gene. Moreover, the Kiss 1 receptor was highly expressed, leading to an increased number of GnRH3 neurons in the hypothalamus [62]. GnRH3 neuron is a neuromodulator that indirectly controls the pituitary gonadal axis of the reproductive system in zebrafish [91,92]. Furthermore, Yang et al. [56] found that male zebrafish in an aquarium containing 0.1 and $1 \mathrm{mg} / \mathrm{L} \mathrm{BPF}$ showed an increase in the expression of GnRH receptors (GnRHR1 and GnRHR2), which influences the increase of GnRH neurons. Another BPA analogue, BPAF, has also been reported to disturb the HPG axis in the offspring of male zebrafish by increasing the mRNA expression of gnrh2, $f \operatorname{sh} \beta$, and $\operatorname{lh} \beta$ [74]. In zebrafish, gnrh 2 , fsh $\beta$, and $\operatorname{lh} \beta$ are orthologous to human GNRH2, FSH $\beta$, and $\mathrm{LH} \beta$, respectively.

$\mathrm{BPA}$ and its analogues also showed the ability to interfere with ER $\alpha$ in in vivo and in vitro studies. The BPA and its analogues, BPF and BPAF, increased the binding affinity towards ER $\alpha$, while BPS has no effect on this receptor in zebrafish embryos [59]. This observation is supported by in vivo studies where subcutaneous exposure to BPA at a dose of $50 \mathrm{mg} / \mathrm{kg} / \mathrm{bw}$ for two days increased the expression of ER $\alpha$ in the hypothalamus [73]. The same finding was also shown in the transgenic zebrafish embryo exposed to BPA and BPS at doses of $1000 \mu \mathrm{g} / \mathrm{L}$ and $100 \mu \mathrm{g} / \mathrm{L}$, respectively. In contrast, perinatal exposure to BPA at a dose of $50 \mu \mathrm{g} / \mathrm{kg} / \mathrm{bw}$ via drinking water caused a decrease in the expression of both ER $\alpha$ and $\beta$ in the hypothalamus of male Wistar rats during adulthood [71]. The increase of Kiss1 expression in the brain increases GnRH secretion, stimulating LH and FSH secretion. A study by Bai et al. [72] found that perinatal exposure to BPA at a dose of $2 \mu \mathrm{g} / \mathrm{kg} / \mathrm{bw}$ increased the GnRH neuron in the brain, leading to an increase in LH levels in the blood of male rat offspring.

In contrast, several previous studies have reported a decrease in the FSH and LH levels in the blood of adult male rats when exposed to various dosages of BPA ranging from $25 \mathrm{mg} / \mathrm{kg} / \mathrm{bw}$ to $200 \mathrm{mg} / \mathrm{kg} / \mathrm{bw}$ either via oral gavage or intraperitoneal injection $[64-67,75-77,80]$. A similar finding was also shown in rats who were exposed to BPA 
analogues. A study by Ullah et al. [68] showed that BPF at a dose of $1 \mathrm{mg} / \mathrm{kg} / \mathrm{bw}$ via oral gavage significantly reduced the LH and FSH levels in the plasma of male rats. Therefore, from the previous findings, we may assume that BPA and its analogues at a lower dosage may increase LH and FSH levels via Kiss1 expression. However, a contrasting finding was noted when BPA was exposed at a higher dosage. LH in the blood binds to the LH receptor on the LC membrane to stimulate testosterone synthesis [93]. A previous study reported a decrease in the testosterone levels in the blood of adult male rats when exposed to BPA either during adulthood or exposure of offspring via oral gavage, subcutaneously, or intraperitoneal injection [64-66,75-77,80].

Furthermore, exposure to BPF and BPS for 28 days in male rats also decreased testicular and plasma testosterone [52,68-70]. BPA and its analogues, BPF and BPAF, also caused a decrease in testosterone levels in the plasma or testis of male rats and zebrafish [42,72,74-76]. In contrast, a study by Stoker et al. [71] reported that perinatal exposure to BPA at a dose of $50 \mu \mathrm{g} / \mathrm{kg} / \mathrm{bw}$ via drinking water caused an increase in the testosterone level of male Wistar rats during their adulthood. The contradictory results might be due to the dose, route, and length of BPA exposure. The effects of BPA and its analogues on the correlation between Kiss1, ER $\alpha$, and GnRH in the brain with the levels of FSH, LH, and testosterone in the plasma is still doubtful. The differences may be due to the different doses, way of exposure, types of animals, and study duration. There might also be other mechanisms involving the correlation; for instance, the bisphenols can disrupt the mechanism of negative/positive feedback system in regulating the reproductive hormones or may do so via competitive inhibition at the receptor level either in the brain or the testis. Table 1 shows a summary of the effect of BPA and its analogues on the HPG axis involving the male reproductive system.

Table 1. The effects of BPA and its analogues on the hypothalamus-pituitary-gonadal axis in male reproductive system.

\begin{tabular}{|c|c|c|c|c|c|c|}
\hline $\begin{array}{l}\text { Type of } \\
\text { Bisphenol }\end{array}$ & $\begin{array}{c}\text { Purity } \\
\text { (Manufacturer) }\end{array}$ & Dose (Route) & Animal & $\begin{array}{l}\text { Duration of } \\
\text { Exposure }\end{array}$ & Findings & Author \\
\hline BPA & $\begin{array}{l}99 \% \\
\text { (Sigma-Aldrich, } \\
\text { St. Louis, MO, } \\
\text { USA) }\end{array}$ & $\begin{array}{l}50 \mu \mathrm{g} / \mathrm{kg} / \mathrm{bw} \\
\text { (drinking } \\
\text { water) }\end{array}$ & $\begin{array}{l}\text { Adult male } \\
\text { Wistar rats }\end{array}$ & $\begin{array}{l}\text { Perinatal } \\
\text { exposure (From } \\
\text { gestation day } 9 \\
\text { until lactation } \\
\text { day 20) }\end{array}$ & $\begin{array}{c}\uparrow \text { Kiss1 mRNA expression } \\
\text { (hypothalamus) } \\
\downarrow \text { ER } \alpha, \text { ER } \beta \\
\text { (hypothalamus) } \\
\uparrow \text { testosterone (blood) } \\
\downarrow \text { estradiol (blood) }\end{array}$ & [71] \\
\hline $\mathrm{BPA}$ & $\begin{array}{l}>99 \% \text { (Sigma- } \\
\text { Aldrich) }\end{array}$ & $\begin{array}{c}2 \mu \mathrm{g} / \mathrm{kg} / \mathrm{bw} \\
\text { (s.c) }\end{array}$ & $\begin{array}{l}\text { Offspring male } \\
\text { SD }\end{array}$ & $\begin{array}{c}\text { Perinatal } \\
\text { exposure Day } \\
10 \text { of gestation } \\
\text { until day } 7 \text { of } \\
\text { lactation }\end{array}$ & $\begin{array}{c}\uparrow \text { Kiss1 mRNA expression } \\
\text { (brain) } \\
\uparrow \text { GnRH neuron } \\
\uparrow \text { LH, estradiol (blood) } \\
\downarrow \text { testosterone (blood) }\end{array}$ & {$[72]$} \\
\hline $\mathrm{BPA}$ & - & $\begin{array}{l}50 \mathrm{mg} / \mathrm{kg} / \mathrm{bw} \\
\text { (s.c.) }\end{array}$ & $\begin{array}{l}\text { Male pup Long } \\
\text { Evans rats }\end{array}$ & $\begin{array}{c}2 \text { days } \\
\text { Postnatal day } \\
0-2\end{array}$ & $\begin{array}{c}\uparrow \text { expression of Kiss1 } \\
\text { (brain) } \\
\uparrow \text { expression of ER } \alpha \text { (brain) }\end{array}$ & [73] \\
\hline $\mathrm{BPA}$ & $\begin{array}{c}\text { MERCK, } \\
\text { Kenilworth, NJ, } \\
\text { USA }\end{array}$ & $\begin{array}{l}50 \mathrm{mg} / \mathrm{kg} / \mathrm{bw} \\
\text { (i.p.) }\end{array}$ & $\begin{array}{l}\text { Adult male SD } \\
\text { rats }\end{array}$ & $\begin{array}{l}\text { Alternate day } \\
\text { until } 21 \text { days }\end{array}$ & $\begin{array}{c}\downarrow \text { FSH, LH, testosterone } \\
\text { (serum) } \\
\uparrow \text { estradiol (serum) }\end{array}$ & [75] \\
\hline $\mathrm{BPA}$ & Sigma-Aldrich & $\begin{array}{c}5 \text { or } 25 \\
\mathrm{mg} / \mathrm{kg} / \mathrm{bw} \\
\text { (oral gavage) }\end{array}$ & $\begin{array}{l}\text { Adult male } \\
\text { Wistar rats }\end{array}$ & 40 days & $\begin{array}{c}\uparrow \text { expression of Gnrhr, Lhb, } \\
\text { Fshb, ER } \beta, \text { AR mRNA } \\
\text { (pituitary) } \\
\downarrow \text { Gnrh, ER } \alpha \\
\text { (hypothalamus) } \\
\downarrow \text { FSH, LH, testosterone } \\
\text { (blood) } \\
\uparrow \text { estradiol (blood) }\end{array}$ & [76] \\
\hline
\end{tabular}


Table 1. Cont.

\begin{tabular}{|c|c|c|c|c|c|c|}
\hline $\begin{array}{c}\text { Type of } \\
\text { Bisphenol }\end{array}$ & $\begin{array}{c}\text { Purity } \\
\text { (Manufacturer) }\end{array}$ & Dose (Route) & Animal & $\begin{array}{l}\text { Duration of } \\
\text { Exposure }\end{array}$ & Findings & Author \\
\hline BPA & $\begin{array}{l}>99 \% \text { (Sigma- } \\
\text { Aldrich) }\end{array}$ & $\begin{array}{c}50 \mathrm{mg} / \mathrm{kg} / \mathrm{bw} \\
\text { (oral gavage) }\end{array}$ & $\begin{array}{l}\text { Adult male } \\
\text { Wistar rats }\end{array}$ & 14 days & $\begin{array}{c}\downarrow \mathrm{FSH}, \mathrm{LH}, \text { testosterone } \\
\text { (serum) }\end{array}$ & [77] \\
\hline BPA & Sigma-Aldrich & $\begin{array}{l}50 \mathrm{mg} / \mathrm{kg} / \mathrm{bw} \\
\text { (oral gavage) }\end{array}$ & $\begin{array}{l}\text { Adult male } \\
\text { Wistar rats }\end{array}$ & 30 days & $\begin{array}{c}\downarrow \text { FSH, LH, testosterone, } \\
\text { E2 (plasma) }\end{array}$ & [64] \\
\hline BPA & Sigma-Aldrich & $\begin{array}{c}200 \mathrm{mg} / \mathrm{kg} \\
\text { (oral gavage) }\end{array}$ & $\begin{array}{l}\text { Adult male SD } \\
\text { rats }\end{array}$ & 42 days & $\begin{array}{l}\downarrow \text { FSH, LH, testosterone } \\
\text { (blood) }\end{array}$ & [65] \\
\hline BPA & - & $\begin{array}{l}25 \mathrm{mg} / \mathrm{kg} / \mathrm{bw} \\
\text { (i.p.) }\end{array}$ & $\begin{array}{l}\text { Adult male SD } \\
\text { rats }\end{array}$ & $\begin{array}{l}\text { Alternate day } \\
\text { for } 30 \text { days }\end{array}$ & $\begin{array}{c}\downarrow \mathrm{FSH}, \mathrm{LH}, \text { testosterone } \\
\text { (plasma) }\end{array}$ & [66] \\
\hline BPA & $\begin{array}{l}\text { Gracia chengdu } \\
\text { chemical } \\
\text { technology co, } \\
\text { Chengdu, } \\
\text { Sichuan, China. }\end{array}$ & $\begin{array}{l}200 \mathrm{mg} / \mathrm{kg} \\
\text { (oral gavage) }\end{array}$ & $\begin{array}{l}\text { Adult male SD } \\
\text { rats }\end{array}$ & 28 days & $\begin{array}{l}\downarrow \text { FSH, LH, testosterone } \\
\text { (blood) }\end{array}$ & [67] \\
\hline $\mathrm{BPF}$ & $\begin{array}{l}\text { 99\% purity } \\
\text { (Santa Cruz } \\
\text { Biotechnologie, } \\
\text { Dallas, TX, } \\
\text { USA) }\end{array}$ & $\begin{array}{c}1,5,25,50, \text { and } \\
100 \\
\mathrm{mg} / \mathrm{kg} / \mathrm{bw} \\
\text { (Oral gavage) }\end{array}$ & $\begin{array}{l}\text { Adult male SD } \\
\text { rats }\end{array}$ & 28 days & $\begin{array}{c}\downarrow \text { FSH, LH, testosterone } \\
\quad \text { (plasma) } \\
\downarrow \text { testicular testosterone }\end{array}$ & [68] \\
\hline BPA/BPS & $>98 \%$ & $\begin{array}{c}1000 \mu \mathrm{g} / \mathrm{L} \\
(\mathrm{BPA}) \\
100 \mu \mathrm{g} / \mathrm{L} \text { (BPS) }\end{array}$ & $\begin{array}{l}\text { Transgenic } \\
\text { zebrafish } \\
\text { (embryo) }\end{array}$ & $\begin{array}{l}2 \mathrm{~h} \text { of post } \\
\text { fertilization } \\
\text { until } 25 \text { or } 20 \mathrm{~h} \\
\text { of post } \\
\text { fertilization }\end{array}$ & $\begin{array}{c}\text { BPA: } \\
\uparrow \text { number of GnRH3 } \\
\text { neuron at } 25 \mathrm{hpf} \\
\text { (hypothalamus) } \\
\uparrow \text { expression of Kiss1 } \\
\text { mRNA, Kiss1 receptor, } \\
\text { gnrh3, lh } \beta \text {, and fsh } \beta \text { after } \\
120 \text { h post fertilization } \\
\text { (embryo) } \\
\uparrow \text { expression of ER } \alpha \text { at } 25 \\
\text { hpf } \\
\text { BPS: } \\
\uparrow \text { number of GnRH3 } \\
\text { neuron at } 25 \text { hpf } \\
\text { (hypothalamus) } \\
\uparrow \text { expression of mRNA } \\
\text { Kiss1 and gnrh3 at } 25 \text { hpf } \\
\text { (hypothalamus) } \\
\uparrow \text { expression of ER } \alpha 25 \mathrm{hpf}\end{array}$ & [62] \\
\hline $\mathrm{BPF} / \mathrm{BPS}$ & $\begin{array}{c}\text { 99\% purity } \\
\text { (Santa Cruz } \\
\text { Biotechnologie) }\end{array}$ & $\begin{array}{c}5,50, \text { and } 500 \\
\mathrm{mg} / \mathrm{kg} / \mathrm{bw} \\
\text { (Oral gavage) }\end{array}$ & $\begin{array}{l}\text { Adult male SD } \\
\text { rats }\end{array}$ & 28 days & $\begin{array}{c}\text { BPF: } \\
\downarrow \text { testicular and plasma } \\
\text { testosterone } \\
\text { BPS: } \\
\downarrow \text { testicular and plasma } \\
\text { testosterone }\end{array}$ & [69] \\
\hline $\mathrm{BPF}$ & $\begin{array}{c}\geq 98 \% \\
\text { (J\&K Scientific } \\
\text { Ltd., Newark, } \\
\text { DE, USA) }\end{array}$ & $\begin{array}{l}0.1 \text { and } 1 \mathrm{mg} / \mathrm{L} \\
\text { in aquarium } \\
\text { water } \\
\text { Renewed } 50 \% \\
\text { of water every } \\
2 \text { days }\end{array}$ & Male Zebrafish & 21 days & $\begin{array}{c}\uparrow \text { expression of GnRH2, } \\
\text { GnRH3, GnRHR1, and } \\
\text { GnRHR2 (Brain) } \\
\uparrow \text { FSHR, LHR (testis) } \\
\downarrow \text { testosterone (testis) } \\
\uparrow \text { estradiol (testis) }\end{array}$ & [56] \\
\hline
\end{tabular}


Table 1. Cont.

\begin{tabular}{|c|c|c|c|c|c|c|}
\hline $\begin{array}{c}\text { Type of } \\
\text { Bisphenol }\end{array}$ & $\begin{array}{c}\text { Purity } \\
\text { (Manufacturer) }\end{array}$ & Dose (Route) & Animal & $\begin{array}{l}\text { Duration of } \\
\text { Exposure }\end{array}$ & Findings & Author \\
\hline $\begin{array}{l}\mathrm{BPS} / \mathrm{BPF} / \\
\text { BPAF }\end{array}$ & $\begin{array}{c}98 \% \\
\text { (Sigma- } \\
\text { Aldrich) }\end{array}$ & $\begin{array}{c}\text { In vitro: } \\
\text { BPAF: } 0.076 \mu \mathrm{m} \\
\text { BPA: } 2.8 \mu \mathrm{m} \\
\text { BPF: } 10.6 \mu \mathrm{m}\end{array}$ & $\begin{array}{c}\text { Zebrafish } \\
\text { (embryo and } \\
\text { larvae) }\end{array}$ & $\begin{array}{l}\text { From day } 1 \text { of } \\
\text { hdf until } 7-\mathrm{dpf} \\
\text { larva }\end{array}$ & $\begin{array}{c}\text { BPAF, BPA, BPF: } \\
\uparrow \text { affinity toward binding } \\
\text { of ER } \alpha \text { (in vitro) } \\
\text { BPS: } \\
\text { No affinity toward the ER } \alpha \\
\text { receptor (in vitro) }\end{array}$ & [59] \\
\hline BPS & - & $\begin{array}{l}1,50 \mu \mathrm{g} / \mathrm{kg} / \mathrm{bw} \\
\text { (oral gavage) }\end{array}$ & $\begin{array}{l}\text { Adult male SD } \\
\text { rats }\end{array}$ & 28 days & $\begin{array}{c}\downarrow \text { testicular and plasma } \\
\text { testosterone }\end{array}$ & [70] \\
\hline BPAF & $\begin{array}{c}99 \% \\
\text { (Sigma- } \\
\text { Aldrich) }\end{array}$ & $\begin{array}{c}25 \text { and } \\
125 \mu \mathrm{g} / \mathrm{L}\end{array}$ & $\begin{array}{l}\text { Offspring male } \\
\text { zebrafish } \\
\text { (embryo) }\end{array}$ & $\begin{array}{l}120 \text { days } \\
\text { (exposure } \\
\text { during embryo } \\
\text { and larva } \\
\text { stages) }\end{array}$ & $\begin{array}{c}\uparrow \text { gnrh } 2, \mathrm{fsh} \beta, \mathrm{lh} \beta, \text { and } \\
\text { cyp } 19 \mathrm{~b} \text { in } 125 \mu \mathrm{g} / \mathrm{L} \\
\uparrow \text { estradiol } \\
\downarrow \text { testosterone }\end{array}$ & [74] \\
\hline
\end{tabular}

Abbreviations: $\uparrow$ Increase; $\downarrow$ Decrease.

\section{Bisphenols and Steroidogenesis}

Testicular steroidogenesis is another important process in regulating the normal physiology of the male reproductive system. Steroidogenesis products such as testosterone, oestrogen, inhibin $\mathrm{B}$, and progesterone play an essential role in maintaining the homeostasis of hormones in blood circulation. LC is a well-known site for steroidogenesis, particularly in the male reproductive system [94]. Steroidogenesis occurs in two different locations in the LC: the mitochondria and endoplasmic reticulum [93,94]. LH in the circulation binds to the $\mathrm{LH}$ receptor (LHR) at the LC membrane, thus activating the G protein groups to form the LHR/G protein complex. This complex activates two pathways by increasing cyclic adenosine monophosphate (cAMP) production and allowing the entry of arachidonic acid (AA) into the LC [95]. Next, cAMP activates protein kinase A (PKA) and mitogenactivated protein kinase (MAPK) for the stimulation of the steroidogenic acute regulatory (StAR) protein. This StAR protein is responsible for the transportation and movement of cholesterol from the outer membrane to the inner membrane of mitochondria $[96,97]$.

Meanwhile, the presence of AA in the LC helps control testosterone production by inhibiting cholesterol movement to the mitochondria [98,99]. AA produces prostaglandin-E2 (PGE-2) via the activation of cyclooxygenase-2 (COX-2) and inhibits StAR functions [100-102]. Cholesterol is the primary substrate acting as a precursor in testicular steroidogenesis $[94,96]$. In mitochondria, cholesterol is converted to pregnenolone through the action of CYP11A1 [103]. The pregnenolone then moves into the endoplasmic reticulum, and the steroidogenic cascade of enzyme reaction that takes place involves the CYP450 enzyme (CYP17) and hydroxy steroid dehydrogenase (HSD) enzymes (3ß-HSD and 17 $\beta-H S D)$. The conversion of pregnenolone into testosterone can be divided into two pathways ( $\Delta 4$ and $\Delta 5$ ). These pathways can be alternated depending on the binding affinity of the CYP17 towards the substrates, $17 \alpha$-hydroxy pregnenolone and $17 \alpha$-hydroxyprogesterone, which activate the $\Delta 5$ and $\Delta 4$ pathways, respectively [103]. Humans mainly undertake this activity through the $\Delta 5$ pathway, while rats and mice mostly take the $\Delta 4$ pathway. In normal physiology, in testicular steroidogenesis, the $\Delta 5$ pathway is less prone to be converted to the alternative pathway synthesizing the E2 than the $\Delta 4$ pathway.

Nowadays, growing evidence has demonstrated the ability of bisphenols to disturb the steroidogenesis pathway. StAR, a protein responsible for transporting and moving cholesterol into the mitochondria, is among the proteins affected by exposure to BPA and its analogues. The gene and protein expression of StAR was decreased in adult male rats exposed to BPA for 28 days and 42 days, respectively, at a dose of $200 \mathrm{mg} / \mathrm{kg}$ by oral gavage $[65,67]$. Furthermore, BPA analogues such as BPF, BPAF, and BPS also caused a decrease in the expression of StAR mRNA. The expression of StAR mRNA was decreased 
in BPF and BPAF in the adults and offspring of male zebrafish, respectively [56,74]. Meanwhile, Eladak et al. [78] found that BPF and BPS also significantly decreased the expression of StAR mRNA in mouse foetal testicular cells (mFeTA) at a concentration of 10,000 nmol/L. The disturbance of the StAR mRNA expression may lead to the deterioration of testicular steroidogenesis due to the disturbance in cholesterol transportation and movement into the mitochondria in the LC.

Previous findings have also shown disturbance in the gene and protein expression of cytochrome P450 and HSD enzymes either in the mitochondrial or reticulum endoplasmic of LC, such as CYP11A1, CYP 17A1, 3 $\beta-H S D$, and 17 $\beta$-HSD. Exposure to BPA at a dose of $200 \mathrm{mg} / \mathrm{kg}$ for 28 days reduced the gene expression of CYP11A1 in the testicular mitochondria of male Sprague-Dawley rats [67]. Furthermore, exposure to BPA at the same dose for 42 days also decreased the protein expression of CYP11A1 [65]. In contrast, the expression of CYP11A1 was found to increase in adults and embryos of male zebrafish exposed to BPF and BPAF, respectively [56,74]. The disruption of CYP11A1 either involving the gene or protein expression decreases the conversion of cholesterol to pregnenolone in the mitochondria of LC. The CYP17A1 and 3 $\beta$-HSD gene expression involved in the steroidogenic enzyme cascade in the endoplasmic reticulum also decreased in BPA-intoxicated rats [65]. The 17 $\beta$-HSD, 3 $\beta$-HSD, and CYP17A1 protein expression also decreased in the testis of male Sprague-Dawley rats exposed to BPA [80]. The same findings were also noted with exposure to BPA analogues in either in vivo or in vitro studies. BPF and BPAF exposure decreased CYP17 expression in the testis of zebrafish, while $17 \beta \mathrm{HSD}$ was found to be decreased in the testis of adult male zebrafish after 21 days of exposure to BPF [56,74]. An in vitro study conducted by Eladak et al. [78] found that BPF and BPS at the highest dose $(10,000 \mathrm{nmol} / \mathrm{L})$ caused a decrease in the expression of HSD3 $\beta 1$ and CYP17A1 in mFeTA after three days of exposure.

Furthermore, BPF and BPAF also decreased the gene expression of HSD3 32 and CYP17A1 in the human adrenocortical carcinoma cell line [79]. However, only BPS exposure has been reported to decrease the gene expression of CYP17A1 in the same cell line [79]. Hence, the interference of the steroidogenic enzymes, demonstrated by the changes in the gene and protein expression of $17 \beta-\mathrm{HSD}, 3 \beta-\mathrm{HSD}$, and CYP17A1, may be the reason for the abnormal testosterone level in BPA, BPF, BPS, and BPAF exposure [56,65,74,78,79].

Most exposure to BPA and its analogues causes decreased testosterone levels due to the low level of $\mathrm{LH}$ and the disturbance of the steroidogenic enzyme cascade in the LC [52,56,64-69,72,74-79]. In contrast, Roelofs et al. [55] reported that exposure to BPF and BPS for $48 \mathrm{~h}$ caused an increase in the level of testosterone in the MA-10 LC culture. Moreover, Stoker et al. [71] also reported an increase in the testosterone level in male Wistar rats during their adulthood when exposed to BPA in their perinatal stage [71]. Decreasing testosterone synthesis activates the backdoor pathway, whereby dehydroepiandrosterone (DHEA) is converted into androstenedione (AD). AD is responsible for the $\Delta 4$ pathway, and this pathway poses a high risk of stimulating the overproduction of E2. This backdoor pathway is also known as the alternative pathway in testicular steroidogenesis involving the activation of p450 aromatase. The activation of aromatase is exhibited by the increased gene and protein expression of CYP19A1, which leads to the activation of cAMP. This mechanism causes the overproduction of E2 in the testis, which also presents as an effect of BPA and its analogues [56,59,72,74-76,79]. However, studies conducted by Stoker et al. [71] and Alboghobeish et al. [64] found a decrease in E2 levels in the blood circulation of adult male rats exposed to BPA. The disruption in this steroidogenesis pathway leads to a disturbance in sperm synthesis known as spermatogenesis. Table 2 shows the effects of BPA and its analogues on steroidogenesis in the male reproductive system. 
Table 2. The effects of BPA and its analogues on the steroidogenesis in male reproductive system.

\begin{tabular}{|c|c|c|c|c|c|c|}
\hline $\begin{array}{l}\text { Type of } \\
\text { Bisphenol }\end{array}$ & $\begin{array}{c}\text { Purity } \\
\text { (Manufacturer) }\end{array}$ & Dose (Route) & Animal & $\begin{array}{l}\text { Duration of } \\
\text { Exposure }\end{array}$ & Findings & Author \\
\hline BPA & $\begin{array}{l}\text { 99\% (Sigma- } \\
\text { Aldrich) }\end{array}$ & $\begin{array}{l}50 \mathrm{mg} / \mathrm{kg} / \mathrm{bw} \\
\text { (oral gavage) }\end{array}$ & $\begin{array}{l}\text { Adult male } \\
\text { Wistar rats }\end{array}$ & 14 days & $\downarrow$ testosterone (serum) & [80] \\
\hline BPA & $\begin{array}{l}\text { 99\% (Sigma- } \\
\text { Aldrich) }\end{array}$ & $\begin{array}{l}50 \mu \mathrm{g} / \mathrm{kg} / \mathrm{bw} \\
\text { (drinking } \\
\text { water) }\end{array}$ & $\begin{array}{l}\text { Adult male } \\
\text { Wistar rats }\end{array}$ & $\begin{array}{c}\text { Perinatal } \\
\text { exposure } \\
\text { (gestation day } 9 \\
\text { until lactation } \\
\text { day 20) }\end{array}$ & $\begin{array}{l}\uparrow \text { testosterone (blood) } \\
\downarrow \text { estradiol (blood) }\end{array}$ & [71] \\
\hline BPA & $\begin{array}{l}>99 \% \\
\text { (Sigma- } \\
\text { Aldrich) }\end{array}$ & $\begin{array}{c}2 \mu \mathrm{g} / \mathrm{kg} / \mathrm{bw} \\
\text { (s.c) }\end{array}$ & $\begin{array}{l}\text { Offspring male } \\
\text { SD rats }\end{array}$ & $\begin{array}{c}\text { Perinatal } \\
\text { exposure Day } \\
10 \text { of gestation } \\
\text { until day } 7 \text { of } \\
\text { lactation }\end{array}$ & $\begin{array}{c}\uparrow \text { estradiol (blood) } \\
\downarrow \text { testosterone (blood) }\end{array}$ & {$[72]$} \\
\hline BPA & Sigma-Aldrich & $\begin{array}{c}5 \text { or } 25 \\
\mathrm{mg} / \mathrm{kg} / \mathrm{bw} \\
\text { (oral gavage) }\end{array}$ & $\begin{array}{l}\text { Adult male } \\
\text { Wistar rats }\end{array}$ & 40 days & $\begin{array}{l}\downarrow \text { testosterone (blood) } \\
\quad \uparrow \text { estradiol (blood) }\end{array}$ & [76] \\
\hline BPA & MERCKS & $\begin{array}{l}50 \mathrm{mg} / \mathrm{kg} / \mathrm{bw} \\
\text { (i.p.) }\end{array}$ & $\begin{array}{l}\text { Adult male SD } \\
\text { rats }\end{array}$ & $\begin{array}{l}\text { Alternate day } \\
\text { until } 21 \text { days }\end{array}$ & $\begin{array}{l}\downarrow \text { testosterone (serum) } \\
\uparrow \text { estradiol (serum) }\end{array}$ & [75] \\
\hline $\mathrm{BPA}$ & $\begin{array}{l}\text { Gracia chengdu } \\
\text { chemical } \\
\text { technology co. }\end{array}$ & $\begin{array}{c}200 \mathrm{mg} / \mathrm{kg} \\
\text { (oral gavage) }\end{array}$ & $\begin{array}{l}\text { Adult male SD } \\
\text { rats }\end{array}$ & 28 days & $\begin{array}{c}\downarrow \text { testosterone (blood) } \\
\downarrow \text { expression of mRNA } \\
\text { StAR, CYP11A1, 3ß-HSD, } \\
\text { CYP17A1 (testis) }\end{array}$ & [67] \\
\hline $\mathrm{BPA}$ & Sigma-Aldrich & $\begin{array}{c}200 \mathrm{mg} / \mathrm{kg} \\
\text { (oral gavage) }\end{array}$ & $\begin{array}{l}\text { Adult male SD } \\
\text { rats }\end{array}$ & 42 days & $\begin{array}{c}\downarrow \text { testosterone (blood) } \\
\downarrow \text { expression of protein } \\
\text { StAR, CYP11A1, 17 } \beta \text {-HSD, } \\
3 \beta \text {-HSD, CYP17A1 (testis) }\end{array}$ & {$[65]$} \\
\hline BPA & Sigma-Aldrich & $\begin{array}{l}50 \mathrm{mg} / \mathrm{kg} / \mathrm{bw} \\
\text { (oral gavage) }\end{array}$ & $\begin{array}{l}\text { Adult male } \\
\text { Wistar rats }\end{array}$ & 30 days & $\begin{array}{c}\downarrow \text { testosterone, estradiol } \\
\text { (plasma) }\end{array}$ & [64] \\
\hline $\mathrm{BPA}$ & - & $\begin{array}{l}25 \mathrm{mg} / \mathrm{kg} / \mathrm{bw} \\
\text { (i.p.) }\end{array}$ & $\begin{array}{l}\text { Adult male SD } \\
\text { rats }\end{array}$ & $\begin{array}{l}\text { Alternate day } \\
\text { of } 30 \text { days }\end{array}$ & $\downarrow$ testosterone (plasma) & [66] \\
\hline $\mathrm{BPF}$ & $\begin{array}{c}99 \% \\
\text { (Santa Cruz } \\
\text { Biotechnologie) }\end{array}$ & $\begin{array}{c}1,5,25,50, \text { and } \\
100 \\
\mathrm{mg} / \mathrm{kg} / \mathrm{bw}\end{array}$ & $\begin{array}{l}\text { Adult male SD } \\
\text { rats }\end{array}$ & 28 days & $\begin{array}{c}\downarrow \text { testosterone (plasma) } \\
\downarrow \text { testosterone (testis) }\end{array}$ & [68] \\
\hline $\mathrm{BPF} / \mathrm{BPS}$ & $\begin{array}{c}99 \% \\
(\text { Santa Cruz } \\
\text { Biotechnologie) }\end{array}$ & $\begin{array}{l}5,50, \text { and } 500 \\
\mathrm{mg} / \mathrm{kg} / \mathrm{bw}\end{array}$ & $\begin{array}{l}\text { Adult male SD } \\
\text { rats }\end{array}$ & 28 days & $\begin{array}{c}\text { BPF: } \\
\downarrow \text { testicular and plasma } \\
\text { testosterone } \\
\text { BPS: } \\
\downarrow \text { testicular and plasma } \\
\text { testosterone }\end{array}$ & [69] \\
\hline $\mathrm{BPF}$ & $\begin{array}{c}\geq 98 \% \\
\text { (J\&K Scientific } \\
\text { Ltd) }\end{array}$ & $\begin{array}{l}0.1 \text { and } 1 \mathrm{mg} / \mathrm{L} \\
\text { in aquarium } \\
\text { water }\end{array}$ & Male Zebrafish & 21 days & $\begin{array}{c}\downarrow \text { testosterone } \\
\text { (homogenate) } \\
\uparrow \text { estradiol (homogenate) } \\
\uparrow \text { expression of CYP19A1b } \\
\text { (aromatase)(Brain) } \\
\uparrow \text { expression of mRNA } \\
\text { CYP11A, CYP19A (testis) } \\
\downarrow \text { expression of mRNA } \\
\text { StAR, CYP17, 17ßHSD } \\
\text { (testis) }\end{array}$ & [56] \\
\hline
\end{tabular}


Table 2. Cont.

\begin{tabular}{|c|c|c|c|c|c|c|}
\hline $\begin{array}{c}\text { Type of } \\
\text { Bisphenol }\end{array}$ & $\begin{array}{c}\text { Purity } \\
\text { (Manufacturer) }\end{array}$ & Dose (Route) & Animal & $\begin{array}{l}\text { Duration of } \\
\text { Exposure }\end{array}$ & Findings & Author \\
\hline $\begin{array}{l}\mathrm{BPS} / \mathrm{BPF} / \\
\mathrm{BPAF}\end{array}$ & $\begin{array}{c}98 \% \\
\text { (Sigma- } \\
\text { Aldrich) }\end{array}$ & $\begin{array}{l}\text { In vivo: } 1 \mu \mathrm{m} \\
\text { In vitro: } \\
\text { BPAF: } 0.076 \mu \mathrm{m} \\
\text { BPA: } 2.8 \mu \mathrm{m} \\
\text { BPF: } 10.6 \mu \mathrm{m}\end{array}$ & $\begin{array}{c}\text { Zebrafish } \\
\text { (embryo and } \\
\text { larvae) }\end{array}$ & $\begin{array}{l}\text { From day } 1 \text { of } \\
\text { hdf until } 7-d p f \\
\text { larva }\end{array}$ & $\begin{array}{c}\text { BPAF, BPF, BPS: } \\
\uparrow \text { expression of mRNA } \\
\text { CYP19A1 gene in 7-dpf } \\
\text { (embryo) }\end{array}$ & [59] \\
\hline BPS & - & $\begin{array}{l}1,50 \mu \mathrm{g} / \mathrm{kg} / \mathrm{bw} \\
\text { (oral gavage) }\end{array}$ & $\begin{array}{l}\text { Adult male SD } \\
\text { rats }\end{array}$ & 28 days & $\begin{array}{c}\downarrow \text { testicular and plasma } \\
\text { testosterone }\end{array}$ & [70] \\
\hline BPAF & $\begin{array}{c}99 \% \\
\text { (Sigma- } \\
\text { Aldrich) }\end{array}$ & $\begin{array}{c}25 \text { and } \\
125 \mu \mathrm{g} / \mathrm{L}\end{array}$ & $\begin{array}{l}\text { Offspring male } \\
\text { zebrafish } \\
\text { (embryo) }\end{array}$ & $\begin{array}{l}120 \text { days } \\
\text { through } \\
\text { exposure of } \\
\text { embryo and } \\
\text { larva stages } \\
\text { - }\end{array}$ & $\begin{array}{c}\uparrow \text { estradiol } \\
\downarrow \text { testosterone } \\
\uparrow \text { CYP19b (brain) } \\
\uparrow \text { expression of mRNA } \\
\text { CYP19A and CYP11A1 } \\
\text { (testis) } \\
\downarrow \text { expression of mRNA } \\
\text { StAR and CYP17 (testis) }\end{array}$ & [74] \\
\hline $\mathrm{BPF} / \mathrm{BPS}$ & $\begin{array}{l}\mathrm{BPF}(>99 \%) \\
\mathrm{BPS}(>98 \%)\end{array}$ & $\begin{array}{c}\text { BPF: } \\
0.01-100 \mu \mathrm{M} \\
\text { BPS: } \\
0.01-30 \mu \mathrm{M}\end{array}$ & $\begin{array}{l}\text { MA-10 Leydig } \\
\text { cell culture }\end{array}$ & $48 \mathrm{~h}$ & $\begin{array}{c}\text { BPF, BPS: } \\
\uparrow \text { testosterone secretion } \\
\uparrow \text { expression of } 5 \alpha \operatorname{Red} 1\end{array}$ & [55] \\
\hline $\mathrm{BPF} / \mathrm{BPS}$ & - & $\begin{array}{r}10,100,1000 \\
10,000 \mathrm{nmol} / \mathrm{L}\end{array}$ & $\begin{array}{l}\text { Mouse fetal } \\
\text { testis assay } \\
(\mathrm{mFeTA})\end{array}$ & $1-3$ days & $\begin{array}{c}\text { BPF, BPS }(10000 \mathrm{nmol} / \mathrm{L}): \\
\downarrow \text { testosterone secretion } \\
\downarrow \text { expression of mRNA } \\
\text { StAR, HSD3 } 11 \text { and } \\
\text { CYP17A1 }\end{array}$ & [78] \\
\hline $\begin{array}{l}\mathrm{BPF} / \mathrm{BPS} / \\
\text { BPAF }\end{array}$ & $\begin{array}{c}\text { BPF }(99 \%) \\
\text { BPS (98\%) } \\
\text { BPAF }(99 \%)\end{array}$ & $\begin{array}{l}0.1,1,10,30,50 \\
\text { and } 70 \mu \mathrm{M}\end{array}$ & $\begin{array}{c}\text { Human } \\
\text { adrenocortical } \\
\text { carcinoma cell } \\
\text { line (H295R) }\end{array}$ & - & $\begin{array}{c}\text { BPF: } \\
\uparrow \text { estradiol and } \\
\text { progesterone secretion } \\
\text { (dose-dependent manner) } \\
\downarrow \text { expression of mRNA } \\
\text { HSD3 } \beta 2(50 \mu \mathrm{M} \text { ) and } \\
\text { CYP17A1 (dose-dependent } \\
\text { manner) } \\
\text { BPS: } \\
\downarrow \text { testosterone secretion } \\
\text { (dose-dependent manner) } \\
\downarrow \text { expression of mRNA } \\
\text { CYP17A1 } \\
\text { BPAF: } \\
\downarrow \text { testosterone secretion } \\
\text { (dose-dependent manner) } \\
\uparrow \text { progesterone secretion } \\
\downarrow \text { expression of mRNA } \\
\text { CYP17A1, HSD3ß2 }\end{array}$ & [79] \\
\hline
\end{tabular}

Abbreviations: $\uparrow$ Increase; $\downarrow$ Decrease.

\section{Bisphenols and Spermatogenesis}

Spermatogenesis occurs within the seminiferous tubules in the testis. The germ cells, such as spermatogonia, spermatocyte, and spermatid, undergo various stages of spermatogenesis to form sperm. Spermatogenesis occurs via specific processes, such as proliferation, differentiation, mitosis, meiosis, and spermiogenesis, to develop mature spermatozoa. Among these specific processes, proliferation, differentiation, and mitosis occur in the basement membrane, while the remaining processes occur in the adluminal compartment [104]. The blood-testis barrier (BTB) is formed after the basal membrane to protect the microenvironment of the adluminal compartment for the processes relevant to 
that area. Therefore, the germ cells found in the basement membrane are more vulnerable to any toxicants than the germ cells found in the adluminal compartment [93]. The integrity of the BTB is also crucial because changes in its structure may affect the production and morphological structure of the sperm [95]. Spermatogenesis involves not only different stages of germ cells but also SCs. These cells secrete pyruvate and lactate to nourish germ cells during their development and are responsible for the organization of the germ cells [103]. Therefore, any disturbance in the SC causes degeneration and disorganization of the germ cells. Testosterone plays a critical role in spermatogenesis owing to its ability for BTB maintenance, meiosis, Sertoli-spermatid adhesion, and the release of mature spermatozoa [104]. Testosterone maintains the remodelling of the BTB by binding with AR to form the protein involved in the integrity of tight junctions. Testosterone is needed in the completion of meiosis during the development of spermatocytes. Moreover, testosterone also plays an essential role in preventing the elongated spermatid from being released earlier. However, the testosterone hormone helps release the mature spermatozoa into the lumen of the seminiferous tubule, thus preventing spermatozoa from being engulfed by the SC [104].

BPA and its analogues were reported to disturb spermatogenesis by diminishing the BTB integrity, changing testicular histopathology, and causing sperm defects [52,64-70,75-77,80,81]. A study carried out by Li et al. [105] found a disturbance in the BTB of male Wistar rats, which was proven by the reduction of occludin and nectin-3 when exposed to BPA in a dose-dependent manner. The reduction of occludin was also found in the SCs, which were exposed to BPA in in vitro studies [82,83]. Furthermore, both studies also showed a decrease in the ZO-1 protein level $[82,83]$. The disturbances of these proteins lowered the integrity of BTB, which was proven by the reduction in cell viability and androgen receptor (AR) after $6 \mathrm{~h}$ of BPA exposure [82]. Moreover, Feng et al. [83] also found that the reduction of occludin and ZO-1 in SCs significantly perturb the tight junction barrier, lowering the integrity of the BTB. The disruption of BTB integrity may allow germ cells in the adluminal compartment to be exposed to toxicants, leading to the disturbance of spermatogenesis in the seminiferous tubules.

Spermatogenesis disruption after exposure to BPA and its analogues can be shown by histological observations, such as reduction in the diameter and epithelial height of germ cells, atrophy and separation of germinal epithelium, and irregular seminiferous tubule structure $[66,67,80]$. Previous studies reported that BPA exposure causes histopathological changes, proven by the vacuolation, degeneration, and disorganization of germ cells $[66,67,80]$. The vacuolation and degeneration of germ cells were reported after BPA exposure either via oral gavage for 52 days or intraperitoneal injection on alternate days for 30 days in adult male Sprague-Dawley rats $[66,80]$. The spermatogenesis process was found to be weak, arrested in the seminiferous tubule of adult male Wistar rats exposed to BPA at a dose of $50 \mathrm{mg} / \mathrm{kg}$ via oral gavage for 14 days [77]. Furthermore, the same study also found that spermatocytes are among the most affected germ cells in BPA-intoxicated rats [77]. Wang et al. [67] found that BPA at a dose of $200 \mathrm{mg} / \mathrm{kg}$ via oral gavage caused disorganization of germ cells [67]. However, these changes were not observed in BPA analogue-intoxicated rats. Moreover, BPA analogues such as BPF and BPS cause spermatids to become longer, and the absence of mature spermatozoa in the lumen of seminiferous tubules disrupts spermatogenesis in adult male Sprague-Dawley rats [65,68,69]. According to Liang et al. [81], BPA and its analogues (BPS and BPAF) decrease cell viability and increase the DNA damage of the spermatogonia cell line (C18-4). Among these bisphenols, BPAF causes significant outcomes at the lowest concentrations within $24 \mathrm{~h}$ of exposure [81].

BPA and its analogues disrupt spermatogenesis, leading to the deterioration of its outcome, which is proven by a reduction in sperm quality. Low sperm production induced by toxicants is usually associated with oxidative stress and the reduction of testosterone in the blood circulation $[49,106]$. Furthermore, the reduction in sperm development may also be due to abnormal SC causing insufficient nutrition, which is necessary for spermato- 
genesis [105]. According to previous studies, adult male rats' exposure to BPA causes a decrease in sperm quality, proven by a reduction in sperm production, count, motility, viability, and the integrity of sperm acrosome and plasma membrane mitochondrial activity [64-67,75-77]. BPA at a dose of $50 \mathrm{mg} / \mathrm{kg} / \mathrm{bw}$ for 14 days caused mild oedema in the LC, leading to a reduction in testosterone, thus lowering the sperm quality of adult male Wistar rats [77]. There is also an association reported between mitochondrial activity and motility in sperm because the mitochondria is the only source of ATP that enables the energy production necessary for sperm movement [76]. The sperm-specific ion calcium $\left(\mathrm{Ca}^{2+}\right)$ channel (CatSper) is also crucial for sperm motility, hyperactivation, and acrosome reaction. This $\mathrm{pH}$-sensitive channel is responsible for providing enough $\mathrm{Ca}^{2+}$ for sperm function [107]. Progesterone is a factor that influences the activation of the CatSper channel for sperm hyperactivation and acrosomal reaction to penetrate the oocyte [107]. Previous findings reported that the expression of the CatSper channel and charges were significantly downregulated and decreased after exposure to 10, 50, and $250 \mu \mathrm{g} / \mathrm{kg} / \mathrm{kg}$ doses of BPA to the sperm mice orally [84]. These reductions parallel the finding where the motility and acrosome reaction in the presence of progesterone were significantly decreased as well. Exposure of healthy human sperm to $10 \mu \mathrm{M}$ BPA analogues showed a similar effect on the CatSper channel's ability. In a study, the scholars found that BPG, BPAF, BPBP, BPC, and BPB are potent chemicals that inhibit progesterone-induced $\mathrm{Ca}^{2+}$ [85]. These BPA analogues are shown to affect $\mathrm{Ca}^{2+}$ signaling, which can interfere with normal CatSper signaling and result in infertility [85]. Table 3 shows the effects of BPA and its analogues on spermatogenesis in the male reproductive system.

Table 3. The effects of BPA and its analogues on spermatogenesis in the male reproductive system.

\begin{tabular}{|c|c|c|c|c|c|c|}
\hline $\begin{array}{l}\text { Type of } \\
\text { Bisphenol }\end{array}$ & $\begin{array}{c}\text { Purity } \\
\text { (Manufacturer) }\end{array}$ & Dose (Route) & Animal & $\begin{array}{l}\text { Duration of } \\
\text { Exposure }\end{array}$ & Findings & Author \\
\hline BPA & MERCK & $\begin{array}{l}50 \mathrm{mg} / \mathrm{kg} / \mathrm{bw} \\
\text { (i.p.) }\end{array}$ & $\begin{array}{l}\text { Adult male SD } \\
\text { rats }\end{array}$ & $\begin{array}{l}\text { Alternate day } \\
\text { until } 21 \text { days }\end{array}$ & $\begin{array}{c}\text { Sperm: } \\
\downarrow \text { sperm count, motility, viability }\end{array}$ & [75] \\
\hline BPA & Sigma-Aldrich & $\begin{array}{c}50 \mathrm{mg} / \mathrm{kg} / \mathrm{bw} \\
\text { (Oral } \\
\text { gavage) }\end{array}$ & $\begin{array}{l}\text { Adult male SD } \\
\text { rats }\end{array}$ & 52 days & $\begin{array}{l}\text { Histopathology: } \\
\text { Vacuolated and degeneration of } \\
\text { germ cells }\end{array}$ & [80] \\
\hline BPA & Sigma-Aldrich & $\begin{array}{c}5 \text { or } 25 \\
\mathrm{mg} / \mathrm{kg} / \mathrm{bw} \\
\text { (Oral } \\
\text { gavage) }\end{array}$ & $\begin{array}{l}\text { Adult male } \\
\text { Wistar rats }\end{array}$ & 40 days & $\begin{array}{c}\text { Sperm: } \\
\downarrow \text { total and daily sperm } \\
\text { production, integrity of acrosome, } \\
\text { plasma membrane and } \\
\text { mitochondria activity in sperm }\end{array}$ & [76] \\
\hline BPA & $\begin{array}{c}99 \% \\
\text { (Sigma-Aldrich) }\end{array}$ & $50 \mathrm{mg} / \mathrm{kg} / \mathrm{bw}$ & $\begin{array}{l}\text { Adult male } \\
\text { Wistar rats }\end{array}$ & 14 days & $\begin{array}{c}\text { Histopathology: } \\
\text { Leydig cells mild edema } \\
\text { Spermatocyte depletion } \\
\text { Spermatogenesis from weak to } \\
\text { arrest. } \\
\text { Sperm: } \\
\downarrow \text { daily sperm production, sperm } \\
\text { count, sperm motility }\end{array}$ & [77] \\
\hline BPA & Sigma-Aldrich & $\begin{array}{c}50 \mathrm{mg} / \mathrm{kg} / \mathrm{bw} \\
\text { (Oral } \\
\text { gavage) }\end{array}$ & $\begin{array}{l}\text { Adult male } \\
\text { Wistar rats }\end{array}$ & 30 days & $\begin{array}{c}\text { Histopathology: } \\
\downarrow \text { diameter and epithelial height of } \\
\text { seminiferous tubule } \\
\text { Atrophy and separation of } \\
\text { germinal epithelium } \\
\text { Sperm: } \\
\downarrow \text { sperm count }\end{array}$ & [64] \\
\hline BPA & Sigma-Aldrich & $\begin{array}{l}200 \mathrm{mg} / \mathrm{kg} \\
\text { (Oral } \\
\text { gavage) }\end{array}$ & $\begin{array}{l}\text { Adult male SD } \\
\text { rats }\end{array}$ & 42 days & $\begin{array}{c}\text { Sperm: } \\
\downarrow \text { sperm count, daily sperm } \\
\text { production, motility }\end{array}$ & [65] \\
\hline BPA & - & $\underset{\text { (i.p.) }}{25 \mathrm{mg} / \mathrm{kg} / \mathrm{bw}}$ & $\begin{array}{l}\text { Adult male SD } \\
\text { rats }\end{array}$ & $\begin{array}{l}\text { Alternate day of } \\
\quad 30 \text { days }\end{array}$ & $\begin{array}{c}\text { Histopathology: } \\
\text { Degeneration and vacuolation of } \\
\text { germ cells } \\
\text { Sperm: } \\
\downarrow \text { sperm count, motility, and } \\
\text { viability }\end{array}$ & [66] \\
\hline
\end{tabular}


Table 3. Cont.

\begin{tabular}{|c|c|c|c|c|c|c|}
\hline $\begin{array}{c}\text { Type of } \\
\text { Bisphenol }\end{array}$ & $\begin{array}{c}\text { Purity } \\
\text { (Manufacturer) }\end{array}$ & Dose (Route) & Animal & $\begin{array}{l}\text { Duration of } \\
\text { Exposure }\end{array}$ & Findings & Author \\
\hline BPA & $\begin{array}{l}\text { Gracia chengdu } \\
\text { chemical } \\
\text { technology co. }\end{array}$ & $\begin{array}{l}200 \mathrm{mg} / \mathrm{kg} \\
\text { (Oral } \\
\text { gavage) }\end{array}$ & $\begin{array}{l}\text { Adult male SD } \\
\text { rats }\end{array}$ & 28 days & $\begin{array}{c}\text { Histopathology: } \\
\downarrow \text { quantity of mature sperm, } \\
\text { Longer spermatid } \\
\text { Disorganization of germ cells } \\
\text { Sperm: } \\
\downarrow \text { sperm count, motility }\end{array}$ & {$[67]$} \\
\hline $\mathrm{BPF}$ & $\begin{array}{c}99 \% \\
(\text { Santa Cruz } \\
\text { Biotechnologie) }\end{array}$ & $\begin{array}{c}1,5,25,50,100 \\
\mathrm{mg} / \mathrm{kg} / \mathrm{bw}\end{array}$ & $\begin{array}{l}\text { Adult male SD } \\
\text { rats }\end{array}$ & 28 days & $\begin{array}{c}\text { Histopathology: } \\
\downarrow \text { germinal epithelial height } \\
\text { Absence of sperm in lumen }\end{array}$ & [68] \\
\hline $\mathrm{BPF} / \mathrm{BPS}$ & $\begin{array}{c}99 \% \\
(\text { Santa Cruz } \\
\text { Biotechnologie) }\end{array}$ & $\begin{array}{c}5,50,500 \\
\mathrm{mg} / \mathrm{kg} / \mathrm{bw}\end{array}$ & $\begin{array}{l}\text { Adult male SD } \\
\text { rats }\end{array}$ & 28 days & $\begin{array}{c}\text { Histopathology: } \\
\text { BPF: } \\
\text { Seminiferous tubules irregular } \\
\text { Longer spermatid } \\
\text { BPS: } \\
\text { Absence of sperm in lumen }\end{array}$ & [69] \\
\hline BPS & $\begin{array}{c}99 \% \\
\text { (Santa Cruz } \\
\text { Biotechnologie) }\end{array}$ & $\begin{array}{c}25,50 \mu \mathrm{g} / \mathrm{kg} / \mathrm{bw} \\
\text { (Oral } \\
\text { gavage) }\end{array}$ & $\begin{array}{l}\text { Adult male SD } \\
\text { rats }\end{array}$ & 28 days & $\begin{array}{c}\text { Histopathology: } \\
\downarrow \text { epithelial of seminiferous } \\
\text { tubules } \\
\text { Spermatid become longer. }\end{array}$ & {$[70]$} \\
\hline $\begin{array}{c}\mathrm{BPA} / \mathrm{BPAF} \\
\text { /BPS }\end{array}$ & $\begin{array}{l}\text { BPA }(>99 \%) \\
\text { BPS }(98 \%) \\
\text { BPAF }(98 \%)\end{array}$ & $25,50,100 \mu \mathrm{M}$ & $\begin{array}{l}\text { C18-4 } \\
\text { spermatogonial } \\
\text { cell line }\end{array}$ & $24-72 \mathrm{~h}$ & $\begin{array}{c}\text { BPA: } \\
\downarrow \text { the cell viability after } 24 \mathrm{~h} \\
(100 \mu \mathrm{M}) \\
\uparrow \text { DNA damage after } 48 \mathrm{~h}(50 \mu \mathrm{M}) \\
\text { BPAF: } \\
\downarrow \text { the cell viability after } 24 \mathrm{~h} \\
(50 \mu \mathrm{M}) \\
\uparrow \text { DNA damage after } 24 \mathrm{~h}(25 \mu \mathrm{M}) \\
\text { BPS: } \\
\downarrow \text { the cell viability after } 24 \mathrm{~h} \\
\quad(100 \mu \mathrm{M}) \\
\uparrow \text { DNA damage after } 24 \mathrm{~h}(50 \mu \mathrm{M})\end{array}$ & [81] \\
\hline BPA & Sigma-Aldrich & $\begin{array}{c}10 \text { and } 50 \\
\mathrm{mg} / \mathrm{kg} / \mathrm{bw}\end{array}$ & $\begin{array}{l}\text { Adult male wistar } \\
\text { rat }\end{array}$ & - & $\begin{array}{c}\downarrow \text { occludin }(10 \mathrm{mg} / \mathrm{kg} \text { for } 11 \text { weeks } \\
\text { and } 50 \mathrm{mg} / \mathrm{kg} \text { for } 4 \text { weeks }) \\
\downarrow \text { nectin-3 (50 mg/ } \mathrm{kg} \text { for } \\
2-4 \text { weeks) }\end{array}$ & [105] \\
\hline BPA & - & $20 \mu \mathrm{M}$ & Sertoli cells & - & $\begin{array}{c}\downarrow \text { occludin (after } 48 \mathrm{~h} \text { ) } \\
\downarrow \text { Z0-1 (after } 6 \text { and } 48 \mathrm{~h} \text { ) } \\
\downarrow \text { cells viability after } 6 \text { and } 48 \mathrm{~h} \\
\downarrow \text { androgen receptor after } 6 \text { and } \\
48 \mathrm{~h}\end{array}$ & [82] \\
\hline BPA & Sigma-Aldrich & 25 and $100 \mu \mathrm{M}$ & $\begin{array}{l}\text { Sertoli cells } \\
\text { isolated from } 20 \\
\text { days of wistar } \\
\text { rats }\end{array}$ & - & $\begin{array}{c}\downarrow \text { occludin and ZO-1 (both doses) } \\
\uparrow \text { conexxin (both dosage) } \\
\text { Significantly perturb the tight } \\
\text { junction barrier at dosage } 100 \mu \mathrm{M} \\
(p<0.05)\end{array}$ & {$[105]$} \\
\hline BPA & $\begin{array}{l}\text { Sigma-aldrich } \\
\text { (US) }\end{array}$ & $\begin{array}{c}10,50,250 \\
\mu \mathrm{g} / \mathrm{kg} / \mathrm{D} \\
\text { (Oral gavage) }\end{array}$ & $\begin{array}{c}\text { Sperm of } \\
\text { C57BL/6 mice }\end{array}$ & 8 weeks & $\begin{array}{c}\downarrow \text { sperm motility }(p<0.05) \\
\downarrow \text { Progesterone-induced acrosome } \\
\text { reaction }(p<0.05)\end{array}$ & [84] \\
\hline $\begin{array}{l}\text { BPG, BPAF, } \\
\text { BPC, } \\
\text { BADGE, } \\
\text { BPB }\end{array}$ & $\begin{array}{l}\text { Sigma-aldrich } \\
\text { (MO,US) }\end{array}$ & $\begin{array}{c}\mathrm{Ca}^{2+} \text { signal: } \\
10 \mu \mathrm{M} \\
\text { Progesterone- } \\
\text { induced } \mathrm{Ca}^{2+} \\
\text { signal: } \\
\text { BPF: } 5 \mu \mathrm{M} \\
\text { BPAF\&BPBP: } \\
10 \mu \mathrm{M} \\
\text { BPC, BADGE, } \\
\text { BPB: } 50 \mu \mathrm{M}\end{array}$ & $\begin{array}{l}\text { Healthy human } \\
\text { semen }\end{array}$ & - & $\begin{array}{c}\uparrow \mathrm{Ca}^{2+} \text { signaling } \\
\downarrow \text { Progesterone-induced } \\
\mathrm{Ca}^{2+} \text { signal }\end{array}$ & [85] \\
\hline
\end{tabular}




\section{The Effects of BPA and Its Analogues on Male Reproductive Hormones: Human Biological Studies Evidence}

Human epidemiology findings show a strengthened impact of BPA on the male reproductive system, involving the sexual hormones and sperm characteristics, through in vivo and in vitro studies. However, to the best of our knowledge, the number of human studies on the effects of BPA analogues on the male reproductive system focusing on the HPG axis is still limited. Most human studies have shown an association between the presence of BPA and its analogues in biological samples, such as urine and serum, with male sexual hormones and its effects on spermatogenesis outcomes, such as sperm characteristics parameters. A cross-sectional study was carried out between male children and adolescents in the United States of America. This study found a significant association between a high concentration of BPA in the urine and a low level of total testosterone in the serum of male adolescents only [108]. Researchers have estimated that 1 unit of BPA might lower the total testosterone levels by approximately 50\% [108]. The finding prevailed for associations between BPA and other male reproductive hormones, such as AD and FSH, in men who work in the epoxy resin industry in Shanghai, China [109]. Liu et al. [109] found that increased BPA concentration in the urine indicated a significant decrease in $\mathrm{AD}$ and FSH levels in the worker's serum [109]. Another study among men in the same industry in Guangdong, China, also presented the same findings [110]. The researcher found that BPA concentration and the duration of BPA exposure also influence hormone levels. Higher concentration and longer duration of BPA exposure decreased AD levels increasingly. Furthermore, Zhuang et al. [110] also found that a high concentration and a longer duration of BPA exposure also increased the sex hormone binding globulin (SHBG) in the serum of workers in the industry [110]. SHBG is a globulin protein that carries testosterone, dihydrotestosterone (DHT), and E2. Among these hormones, testosterone is carried the most by this protein. Therefore, an increase in SHBG level suggests that the testosterone level has decreased in the serum of the workers exposed to BPA. However, when comparing worker and non-worker groups, no association was found on the levels of SHBG, total testosterone, inhibin B, and AD [110].

Meanwhile, a study by Lassen et al. [111] found that increased BPA concentration in the urine significantly increased the total and free testosterone, $\mathrm{LH}$, and E2 levels in the serum of the population of young men in Denmark [111]. Furthermore, a cross-sectional study conducted by Adoamnei et al. [112] found that increased concentrations of BPA in the urine also present a significant increase in the LH level among the population of young men in Spain. However, no association was found between BPA and FSH, free testosterone, SHBG, inhibin B, or E2 levels in the same population [112]. BPA acts as an anti-androgen agent by its ability to competitively bind to the AR, causing an increase in testosterone levels in circulation. However, even though BPA can bind to AR, it does not have any effects on testosterone, as a massive amount of BPA is required in serum to exhibit any effect as an antagonist towards AR. Therefore, the HPG axis is being induced to secrete LH for steroidogenesis activation in the LC, leading to increasing testosterone formation. This mechanism explains the increased levels of LH and free testosterone reported by Lessen et al. [111] and Adoamnei et al. [112].

BPA is known to raise oestrogenic activity either by stimulating or inhibiting the ER [113]. BPA has been reported to have a higher affinity towards ER $\beta$ than ER $\alpha$ in an in vitro study [112]. The action of BPA towards these receptors appears to be very complex, but the response depends on the presence of the ER subtypes (ER $\alpha$ and ER $\beta)$ and the coregulatory protein, which either acts as a co-activator protein (stimulate) or the co-repressor protein (inhibit) [113]. The stimulation or inhibition of ER causes an increase or decrease of E2 in circulation, respectively [112]. Several studies have reported increasing E2 levels in the blood after exposure to BPA [108,111]. BPA can strongly bind to oestrogen-related receptors, such as ERR- $\gamma$, which interfere with the steroid synthetase functions and gene expression involved in steroidogenesis [110]. BPA has also been identified to bind with the ER at the anterior and posterior pituitary gland, leading to HPG axis disturbance and activation of 
prolactin secretion. The increased prolactin level in men who were occupationally exposed to BPA was evidence for this [109]. Furthermore, BPA can also increase the E2 level by its ability to activate an alternative steroidogenesis pathway. In humans, the $\Delta 5$ pathway is dominant; however, BPA may activate the alternative pathway where DHEA is converted into AD, which has a high incidence of stimulating the overproduction of E2 [109,110].

A retrospective study known as the ELEMENT project was carried out by Ferguson et al. [114], who reported no association between BPA levels found in mothers' urine during pregnancy with SHBG, inhibin B, or free and total testosterone levels in the serum of male children aged between 8 and 14 years in Mexico [114]. Furthermore, the same study also found no association between BPA in the urine of the male children with SHBG, inhibin $\mathrm{B}$, and the free and total testosterone levels in the serum [114]. However, a retrospective study done by Hart et al. [115] found a significant weak positive correlation between BPA in the serum of pregnant women and sperm motility and concentration in the semen of young men aged between 20 and 22 years old in Australia [115]. BPA was found in almost $90 \%$ of the maternal serum sample [115]. Furthermore, other epidemiological studies showed that a high concentration of BPA decreased sperm quality, proven by decreasing sperm concentrations, count, and motility [111,112,116,117]. A study by Lessen et al. [111] found that a high concentration of BPA present in the urine caused a decrease in the percentage of progressively motile sperm in the semen of young men in Denmark [111]. The same finding was reported between BPA and sperm count and concentration in young men aged 18-23 years in Spain. The high BPA concentration found in the urine of young men decreased the sperm count and concentration. However, the sperm motility and morphology in the same study population did not show any alterations [112]. Furthermore, there was no association between BPA and semen analysis, such as sperm morphology, sperm concentration, total sperm count, and semen volume, among fertile men aged over 18 years in Michigan and Texas [118]. Interestingly, BPA has also been identified to affect semen quality in IVF patients in Slovenia, where sperm count, concentration, vitality and motility decreased with the increasing concentration of BPA in the urine [116].

BPA analogues, such as BPS, also presented adverse effects in semen analysis among the population of young men involved in the FEPOS project in Denmark. The semen volume was lowered in subjects who had high BPA in their urine [119]. In contrast, Abou Ghayda et al. [117] found that infertile patients in Boston, MA, USA, with a high BPS concentration showed a high semen volume; however, this semen has a lower sperm concentration [117]. Low sperm concentration was found in infertile patients who were exposed to BPS. The researcher also reported that an increased level of BPS causes a significant decrease in sperm quality among obese or overweight patients who have a BMI $>25 \mathrm{~kg} / \mathrm{m}^{2}$. Therefore, BPS can increase the severity of sperm defects observed in obese or overweight infertile patients. Table 4 summarises human epidemiological studies of BPA and its analogues towards the male reproductive system. 
Table 4. The summary of human epidemiological studies of BPA and its analogues towards male reproductive system.

\begin{tabular}{|c|c|c|c|c|c|c|c|c|c|}
\hline $\begin{array}{l}\text { Type of } \\
\text { Bispheno }\end{array}$ & $\begin{array}{l}\text { Study } \\
\text { Design }\end{array}$ & $\begin{array}{l}\text { Study } \\
\text { Population (Age) } \\
\text { (Project Name) }\end{array}$ & $\begin{array}{l}\text { Country (Sample } \\
\text { Population) }\end{array}$ & $\begin{array}{l}\text { Biological } \\
\text { Sample }\end{array}$ & $\begin{array}{l}\text { [Bisphenol] } \\
\text { Detected in } \\
\text { Biological } \\
\text { Sample (Mean/ } \\
\text { Median) }\end{array}$ & Findings & $\begin{array}{l}\text { Beta } \\
\text { Coefficient }\end{array}$ & $\begin{array}{l}\text { Significant } \\
\text { Values }\end{array}$ & Author \\
\hline BPA & $\begin{array}{l}\text { Cross } \\
\text { sectional } \\
\text { study }\end{array}$ & $\begin{array}{l}\text { Male children } \\
\text { (6-11 y.o) } \\
\text { Male Adolescents } \\
\text { (12-19 y.o) } \\
\text { (NHANES Project) }\end{array}$ & USA $(n=588)$ & $\begin{array}{l}\text { Urine } \\
\text { Serum }\end{array}$ & $\begin{array}{l}\text { Mean: male } \\
\text { children } 1.74 \\
\text { ng/mL (urine) } \\
\text { Mean: male } \\
\text { adolescents } 1.94 \\
\text { ng/mL (urine) }\end{array}$ & $\begin{array}{l}\text { Reproductive hormones: } \\
\text { No association between BPA and reproductive } \\
\text { hormones in male children across the quartiles. } \\
\text { Increased BPA level caused a significant decrease } \\
\text { in TT in male adolescents across the quartiles. }\end{array}$ & $\begin{array}{l}\text { Q2: } \beta=-49.34 \% \\
\text { Q3: } \beta=-36.87 \% \\
\text { Q4: } \beta=-53.70 \%\end{array}$ & $p<0.05$ & [108] \\
\hline BPA & $\begin{array}{l}\text { Cross } \\
\text { sectional } \\
\text { study }\end{array}$ & $\begin{array}{l}\text { Male worker of } \\
\text { epoxy resin } \\
\text { manufacturer } \\
(16-63 \text { y.o })\end{array}$ & $\begin{array}{l}\text { Shanghai, China } \\
(n=592)\end{array}$ & $\begin{array}{l}\text { Urine } \\
\text { Serum }\end{array}$ & $\begin{array}{l}\text { Median } \\
\text { occupational } \\
\text { exposure: } 685.9 \\
\mu \mathrm{g} / \mathrm{g} \text { Cr (urine) } \\
\text { Median } \\
\text { non-occupational } \\
\text { exposure: } 4.2 \\
\mu \mathrm{g} / \mathrm{gCr} \text { (urine) }\end{array}$ & $\begin{array}{l}\text { Reproductive hormones: } \\
\text { Increased level of BPA cause } \\
\text { significant increase in: } \\
\text { Prolactin } \\
\quad \text { SHBG } \\
\text { - } \quad \text { E2 } \\
\text { across the quartiles } \\
\text { Increased level of BPA cause } \\
\text { significant decreased in levels: } \\
\text { - AD } \\
\text { across the quartiles }\end{array}$ & $\begin{array}{l}\beta=0.0589 \mathrm{ng} / \mathrm{mL} \\
\beta=0.0293 \mathrm{nmol} / \mathrm{L} \\
\beta=0.0362 \mathrm{pg} / \mathrm{mL} \\
\beta=-0.0367 \mathrm{ng} / \mathrm{mL} \\
\beta=-0.024 \mathrm{mIU} / \mathrm{mL}\end{array}$ & $\begin{array}{l}p<0.001 \\
p<0.01 \\
p<0.001 \\
p<0.001 \\
p<0.05\end{array}$ & [109] \\
\hline BPA & $\begin{array}{l}\text { Cross } \\
\text { sectional } \\
\text { study }\end{array}$ & $\begin{array}{l}\text { Male worker of } \\
\text { epoxy resin } \\
\text { manu-facturer }\end{array}$ & $\begin{array}{l}\text { Guang-dong, } \\
\text { China }(n=559)\end{array}$ & Serum & $\begin{array}{l}\text { Median workers: } \\
8.75 \mathrm{ng} / \mathrm{mL} \\
\text { (serum) } \\
\text { Median } \\
\text { non-workers: } 3.37 \\
\text { ng/mL (serum) }\end{array}$ & $\begin{array}{l}\text { Reproductive hormones: } \\
\text { No association between workers and non-workers } \\
\text { on the level of SHBG, TT, INB and AD } \\
\text { Increased exposure time caused significant } \\
\text { decreased in median AD level among workers. } \\
\text { Increased exposure time caused significant } \\
\text { increase in median SHBG level among workers. } \\
\text { Increased BPA level caused significant increase in } \\
\text { median SHBG level among workers. } \\
\text { Increased of BPA level caused significant } \\
\text { decreased in median AD level among workers. }\end{array}$ & $\begin{array}{l}- \\
\beta=2.79 \mathrm{nmol} / \mathrm{L} \\
\beta=-0.18 \mathrm{ng} / \mathrm{mL}\end{array}$ & $\begin{array}{l}p<0.001 \\
p<0.05 \\
p<0.05 \\
p<0.001\end{array}$ & [110] \\
\hline
\end{tabular}


Table 4. Cont.

\begin{tabular}{|c|c|c|c|c|c|c|c|c|c|}
\hline $\begin{array}{l}\text { Type of } \\
\text { Bispheno }\end{array}$ & $\begin{array}{l}\text { Study } \\
\text { Design }\end{array}$ & $\begin{array}{l}\text { Study } \\
\text { Population (Age) } \\
\text { (Project Name) }\end{array}$ & $\begin{array}{l}\text { Country (Sample } \\
\text { Population) }\end{array}$ & $\begin{array}{l}\text { Biological } \\
\text { Sample }\end{array}$ & $\begin{array}{l}\text { [Bisphenol] } \\
\text { Detected in } \\
\text { Biological } \\
\text { Sample (Mean/ } \\
\text { Median) }\end{array}$ & Findings & $\begin{array}{l}\text { Beta } \\
\text { Coefficient }\end{array}$ & $\begin{array}{l}\text { Significant } \\
\text { Values }\end{array}$ & Author \\
\hline \multirow[t]{2}{*}{ BPA } & \multirow[t]{2}{*}{$\begin{array}{l}\text { Cross } \\
\text { sectional } \\
\text { study }\end{array}$} & \multirow[t]{2}{*}{ Young men } & \multirow[t]{2}{*}{$\begin{array}{l}\text { Denmark } \\
(n=308)\end{array}$} & \multirow[t]{2}{*}{$\begin{array}{l}\text { Urine } \\
\text { Serum } \\
\text { Semen }\end{array}$} & \multirow[t]{2}{*}{$\begin{array}{l}\text { Median: } \\
3.74 \mathrm{ng} / \mathrm{mL} \\
\text { (Osm)(urine) }\end{array}$} & 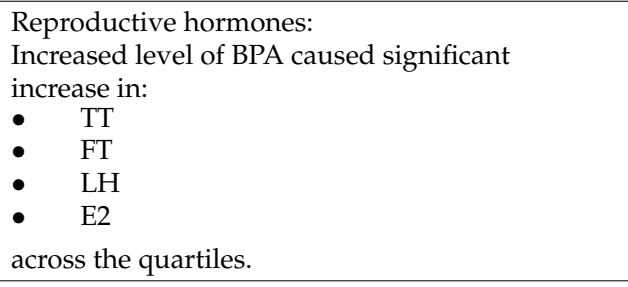 & $\begin{array}{l}\beta=0.7 \mathrm{nmol} / \mathrm{L} \\
\beta=2.7 \% \\
\beta=3.5 \% \\
\beta=2.7 \%\end{array}$ & $\begin{array}{l}p<0.01 \\
p<0.05 \\
p<0.05 \\
p<0.05\end{array}$ & \multirow[t]{2}{*}{ [111] } \\
\hline & & & & & & $\begin{array}{l}\text { Sperm characteristics: } \\
\text { Increased level of BPA caused a significant } \\
\text { decreased in percentage of progressive motile } \\
\text { spermatozoa across the quartiles. }\end{array}$ & $\beta=-1.82 \%$ & $p<0.01$ & \\
\hline \multirow[b]{2}{*}{ BPA } & \multirow[b]{2}{*}{$\begin{array}{l}\text { Cross } \\
\text { sectional } \\
\text { study }\end{array}$} & \multirow[b]{2}{*}{$\begin{array}{l}\text { Young men } \\
\text { (18-23 y.o) }\end{array}$} & \multirow[b]{2}{*}{$\begin{array}{l}\text { Spain } \\
(n=215)\end{array}$} & \multirow[b]{2}{*}{$\begin{array}{l}\text { Urine } \\
\text { Serum } \\
\text { Semen }\end{array}$} & \multirow[b]{2}{*}{$\begin{array}{l}\text { Mean: } \\
1.8 \text { нg/g (urine) }\end{array}$} & $\begin{array}{l}\text { Reproductive hormones: } \\
\text { Increased level of BPA caused significant increase } \\
\text { in LH level across the quartiles. } \\
\text { No association between BPA and FSH, FT, SHBG, } \\
\text { INB and E2 across the quartile. }\end{array}$ & $\beta=0.07 \mathrm{IU} / \mathrm{L}$ & $p<0.01$ & \multirow[b]{2}{*}{ [112] } \\
\hline & & & & & & $\begin{array}{l}\text { Sperm characteristics: } \\
\text { Increased level of BPA caused significant } \\
\text { decreased in sperm characteristic across the } \\
\text { quartiles: } \\
\text { - concentration } \\
\text { No sperm count } \\
\text { and mociation between BPA and sperm motility } \\
\text { and }\end{array}$ & $\begin{array}{l}\beta=-0.04 \text { Mill. } / \mathrm{mL} \\
\beta=-0.05 \text { Mill. }\end{array}$ & $\begin{array}{l}p<0.01 \\
p<0.01\end{array}$ & \\
\hline BPA & $\begin{array}{l}\text { Retro-spective } \\
\text { cohort }\end{array}$ & $\begin{array}{l}\text { Pregnant woman } \\
\text { Male chil-dren } \\
\text { (8-14 y.o) } \\
\text { (ELEMENT } \\
\text { project) }\end{array}$ & $\begin{array}{l}\text { Mexico } \\
(n=118)\end{array}$ & $\begin{array}{l}\text { Urine } \\
\text { Urine } \\
\text { Serum }\end{array}$ & $\begin{array}{l}\text { Mean: } 0.7 \mathrm{ng} / \mathrm{mL} \\
\text { (urine) } \\
\text { Mean: } 1.1 \mathrm{ng} / \mathrm{mL} \\
\text { (urine) }\end{array}$ & $\begin{array}{l}\text { Reproductive hormones: } \\
\text { No association between prenatal urinary BPA and } \\
\text { the boy sex hormones in the level of SHBG, INB, } \\
\text { TT, E2, DHEAS and FT } \\
\text { No association between child-hood urinary BPA } \\
\text { and the boy sex hormones in the level of SHBG, } \\
\text { INB, TT, E2, DHEAS and FT }\end{array}$ & - & - & [114] \\
\hline
\end{tabular}


Table 4. Cont.

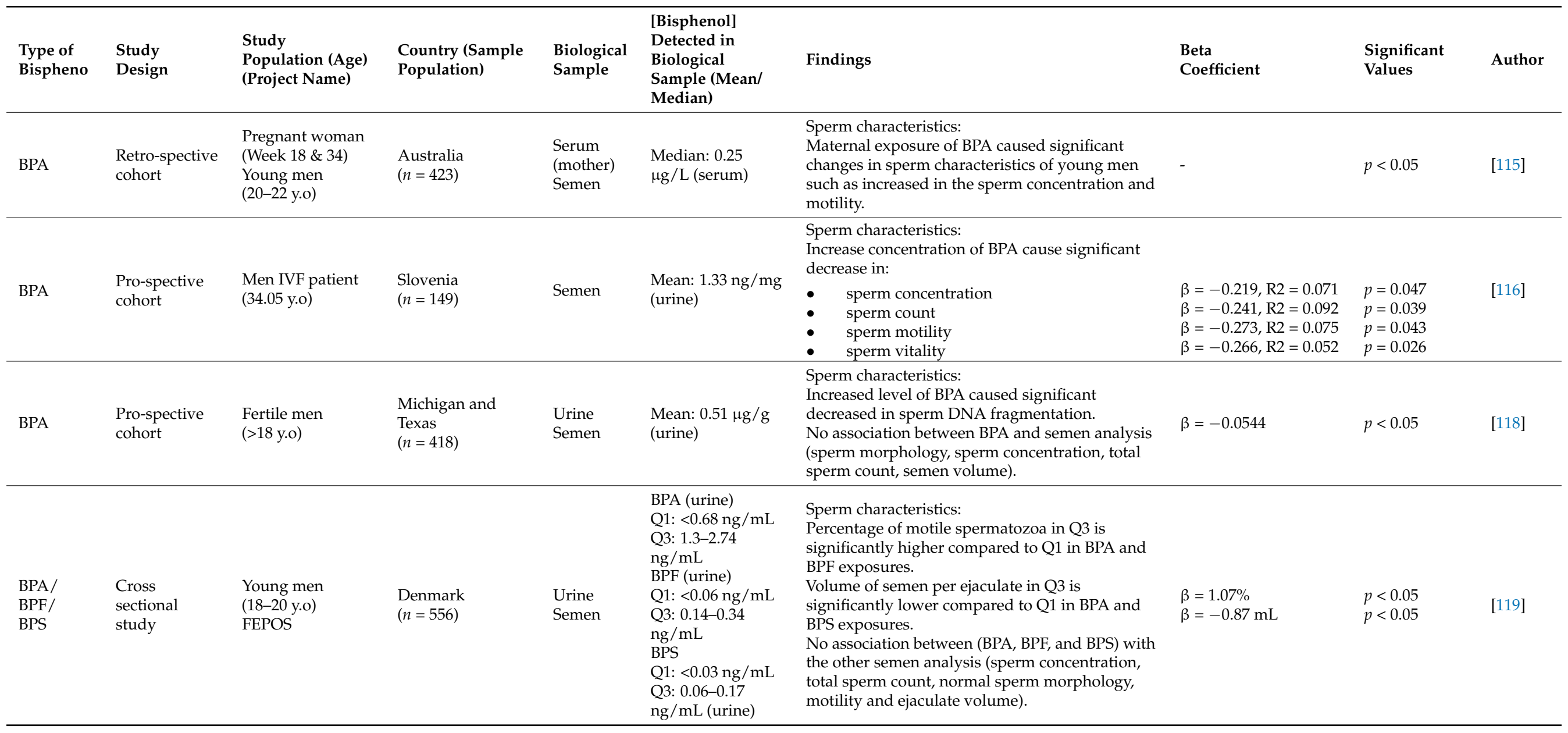


Table 4. Cont.

\begin{tabular}{|c|c|c|c|c|c|c|c|c|c|}
\hline $\begin{array}{l}\text { Type of } \\
\text { Bispheno }\end{array}$ & $\begin{array}{l}\text { Study } \\
\text { Design }\end{array}$ & $\begin{array}{l}\text { Study } \\
\text { Population (Age) } \\
\text { (Project Name) }\end{array}$ & $\begin{array}{l}\text { Country (Sample } \\
\text { Population) }\end{array}$ & $\begin{array}{l}\text { Biological } \\
\text { Sample }\end{array}$ & $\begin{array}{l}\text { [Bisphenol] } \\
\text { Detected in } \\
\text { Biological } \\
\text { Sample (Mean/ } \\
\text { Median) }\end{array}$ & Findings & $\begin{array}{l}\text { Beta } \\
\text { Coefficient }\end{array}$ & $\begin{array}{l}\text { Significant } \\
\text { Values }\end{array}$ & Author \\
\hline BPS & $\begin{array}{l}\text { Cross } \\
\text { sectional } \\
\text { study }\end{array}$ & $\begin{array}{l}\text { Infertile } \\
\text { patient } \\
\text { (18-56 y.o) }\end{array}$ & $\begin{array}{l}\text { Boston, MA, USA } \\
(n=158)\end{array}$ & $\begin{array}{l}\text { Urine } \\
\text { Semen }\end{array}$ & $\begin{array}{l}\text { Mean BPA: } \\
0.77 \mu \mathrm{g} / \mathrm{L} \text { (urine) } \\
\text { Mean BPS: } \\
0.37 \text { gg/L (urine) }\end{array}$ & $\begin{array}{l}\text { Semen characteristics: } \\
\text { Volume of semen per ejaculate in Q2 is } \\
\text { significantly higher compared to Q1 in BPS } \\
\text { exposure. } \\
\text { Sperm concentration in Q3 is significantly lower } \\
\text { compared to Q1 in BPS exposure. } \\
\text { Increased level of BPS caused significant } \\
\text { decreased in sperm quality among } \\
\text { obese/overweight men }\left(\mathrm{BMI}>25 \mathrm{~kg} / \mathrm{m}^{2}\right) \text { : } \\
\text { - } \quad \text { sperm concentration } \\
\text { - total sperm count } \\
\text { total motility }\end{array}$ & $\begin{array}{l}\beta=3.0 \mathrm{~mL} \\
\beta=-29.2 \mathrm{mil} / \mathrm{mL}\end{array}$ & $\begin{array}{l}p<0.05 \\
p<0.05\end{array}$ & [117] \\
\hline
\end{tabular}




\section{Discussion}

There is significant evidence that endocrine disrupting chemicals such as BPA and its analogues are an additional risk factor to be considered. Understanding the link between them and hormonal physiological function in the male reproductive system would aid in ensuring that suitable efforts are made to enhance public awareness and prevent their detrimental impacts on health.

BPA and its analogues have been the topic of extensive research and controversy in recent decades, and the amount of information available about them today is astounding. There are numerous papers that dealing with BPA and its analogues on human health, and the trend is for more to be published in the future. It is considered that the effects of BPA and its analogues on human health are a relatively new field with many unresolved problems. As previously stated, BPA and its analogues are commonly used substances in developing and underdeveloped countries. This means that scientists cannot dismiss the possibility that one of the functions of these compounds is to disturb the endocrine system. Numerous studies, both epidemiological and experimental, published in recent years have contributed to our understanding of some of the features and how they influence the hormonal physiological functions in the male reproductive system.

BPA and its analogues have a negative impact on hormonal physiological functions in the male reproductive system, which have been proven in vitro $[55,78,79]$, in animals $[56,64-70,72,74-77,80]$ and in human studies $[108-111,116,118]$. These hormonal physiological dysfunctions affect spermatogenesis outcomes. Some studies have shown decreased LH, FSH and testosterone levels when exposed to certain concentrations of BPA and its analogues as occurs in the HPG axis, specifically when this exposure occurs during adulthood [64-68,75-77]. The result of this review suggests that BPA and its analogues are capable of competitively binding to AR and ER and stimulating KiSS1 expression in the hypothalamus of the brain, causing the HPG axis feedback mechanism disturbance. These effects will alter GnRH secretion, resulting in variations in pituitary secretion of LH and FSH, with most studies reporting lower levels of these hormones. It is, therefore, logical that experimental animal studies showed low levels of testosterone as the negative feedback mechanism for these phenomena. Furthermore, BPA and 17-beta-oestrogen molecules are structurally similar; therefore, the former can adhere to the ER and mimic the oestrogenic effects in a human study [110,111], which is supported by the animal data $[60,72,73]$. Epidemiology studies have also shown that BPA and its analogues found in human urine are associated with the disturbance of male reproductive hormones via its effects as anti-androgenic and anti-oestrogenic agents [110-112,116].

Not only involving the HPG axis mechanism, BPA and its analogues could interfere with the steroidogenesis pathway via upregulation and downregulation of genes and proteins such as CYP and HSD, causing steroidogenesis disturbance [110,112]. BPA and its analogues can activate an alternative pathway known as the aromatase pathway, which alternates from testosterone synthesis to oestrogen synthesis [110,112]. This aromatase activity happens due to the upregulation of genes and protein expression of CYP19A1, which has been proven in in vitro and animal studies [56,59,74]. One of the primary results of this analysis is that BPA and its analogues have the potential to alter the steroidogenesis pathway, resulting in outcomes that are analogous to those of prostate cancer, such as high oestrogen levels in blood circulation. Therefore, BPA and its analogues exposure could be listed as one of the risk factors for prostate cancer.

In the Section 3 of the findings of this literature review, we examined articles that investigated the effects of BPA and its analogues on spermatogenesis outcomes. The disturbance of male reproductive hormones reduces spermatogenesis outcomes proven by sperm and semen quality defects. Testosterone and FSH play important roles in spermatogenesis; therefore, a decrease in these hormones will result in sperm quality defects, which were reported in animals and cell cultures exposed to BPA and its analogues [64-70,75-77,80-82]. The human findings also reported a decrease in sperm and semen quality when exposed to BPA and its analogues $[111,112,116]$. CatSper channel is another factor that influences 
sperm motility, hyperactivation and acrosomal reaction to penetrate the oocyte. As discussed previously, CatSper is one of the channels found in the sperm responsible for the influx of $\mathrm{Ca}^{2+}$ for sperm function. Therefore, downregulation and alteration in this channel after BPA and its analogues exposure could lead to immotile sperm and reduction in oocyte penetration ability even with the presence of progesterone. All these events in spermatogenesis disturbances lead to sperm quality defects resulting in infertility [85].

The significant drawback of this work is that most publications examine animal studies rather than human studies, owing to the logical and ethical challenges of doing this type of study in humans. Some findings are parallel between humans and animals; however, some findings showed differences, such as the doses used in animal and human studies. The low observed adverse effects level (LOAEL) dose for BPA in a mammalian animal is $50 \mathrm{mg} / \mathrm{kg} / \mathrm{bw}$. Even though the dose of BPA used in the previous studies was below the LOAEL, it reportedly caused changes in the reproductive hormone, sperm characteristic, and histological of the testis in laboratory animals $[66,70-72,76]$. Rats were more susceptible to BPA when compared to humans. Therefore, the adverse effect is more severe in rats, specifically the male reproductive system, proven by the disturbance of reproductive hormone, gene, and protein expression in steroidogenesis and reduced sperm quality.

Even though the BPA concentration found in human urine is lower than the tolerable daily intake (TDI), which is below than $4 \mu \mathrm{g} / \mathrm{kg}$, significant negative effects were found in our literature findings proven by alterations in the reproductive hormones, sperm characteristics, and semen quality. However, the data from human biomonitoring studies are uncertain, which might be due to different metabolism rates in individuals influencing their ability to excrete the BPA [9]. Furthermore, the concentration of BPA and the duration of exposure might also be significant factors that must be considered in assessing the effect of BPA on the hormones' physiological function in the male reproductive system. There are a few possible challenges from the previous literature findings which derive interpretation concern: subject population (fertile versus infertile, young adult versus children; BPA and its analogues exposure levels (due to non-linear effects of BPA); sampling frequency limitations (sample may not be representative of exposure such as retrospective study); and BPA exposure window which may not be related to the spermatogenesis outcomes because the spermatogenesis process in the human takes about three months to be complete [9]. Another problem is that the effects of BPA and its analogues on physiological hormonal functions were explored without taking into account probable interactions with other environmental factors.

Figure 1 shows the possible mechanism of BPA and its analogues on the hormonal physiology pathway of the male reproductive system. BPA and its analogues negatively impact the physiological hormonal functions in the male reproductive system and its outcome, which were proven by sperm and semen quality defects. The BPA and its analogues can alter the HPG axis by increasing the expression of KiSS1 and competitively bind with ER $\alpha$ in the brain's hypothalamus. These effects will influence GnRH secretion, leading to changes in the pituitary secretion of LH and FSH, which most of the studies reported decreased levels of these hormones. Decreased LH levels in the plasma could disturb the steroidogenesis process in Leydig cells, resulting in decreased testosterone levels. Furthermore, these endocrine disrupting chemicals were also reported to alter the StAR protein, HSD and CYP450 genes and enzymes in the mitochondrial and ER of Leydig cells involved in the steroidogenesis pathway. These alterations also lead to the decrease of testosterone synthesis. Therefore, once testosterone synthesis is inhibited, the alternative pathway will be activated. BPA and its analogues can activate this alternative pathway of steroidogenesis by activating aromatase activity, thus increasing the formation of E2. As the consequences of HPG axis disturbance and activation of the alternative steroidogenesis pathway specifically proven by the FSH and testosterone levels decreased, respectively, these phenomena lead to the disturbance of spermatogenesis reported in most studies. Therefore, the spermatogenesis outcome, such as sperm quality, will have deteriorated. 


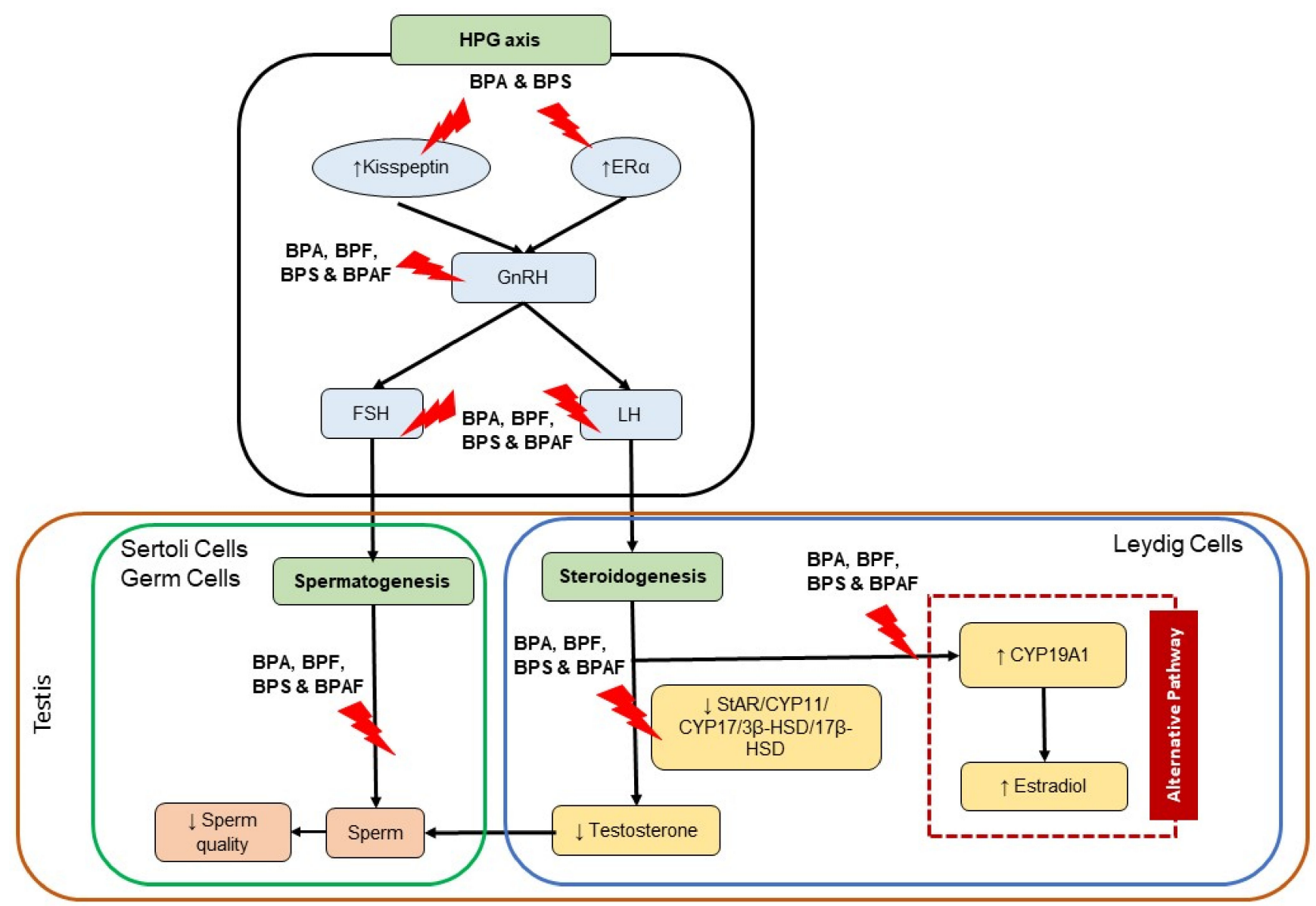

Figure 1. Possible mechanism of BPA and its analogues on the hormonal physiology of male reproductive system. Abbreviations: $\downarrow$ inhibit/decrease, $\uparrow$ enhance/increase.

\section{Conclusions}

In conclusion, BPA and its analogues may be an additional risk factor to consider because they disrupt the hormonal physiological functions of the male reproductive system. The results of the experimental studies mostly point to BPA and its analogues having the ability to disrupt the endocrine system, resulting in HPG axis disturbances and activation of the steroidogenesis alternative pathway, which is why more experimental and epidemiological research will be required to establish the scale of the effects caused by these chemicals in large populations and its molecular mechanism to a better understanding of the connection between HPG axis, steroidogenesis, and spermatogenesis outcomes. Despite the fact that many nations have adopted policies to limit exposure to BPA and its analogues in their populations, epidemiological research on humans imply that the same abnormalities seen in experimental studies on animals may be detected. Understanding the association between BPA and its analogues and physiological hormonal activities can aid in raising public awareness and implementing public health campaigns to prevent exposure to these compounds, particularly among those attempting to conceive and elderly populations.

Author Contributions: Conceptualization, A.'A.S.; N.J.S. and I.S.T.; methodology, A.'A.S.; N.J.S. and I.S.T.; validation, I.S.T.; S.B.B. and Z.A.H.; writing-original draft preparation, A.'A.S.; writingreview and editing, A.'A.S. and I.S.T.; supervision, I.S.T.; S.B.B.; Z.A.H. and N.J.S.; funding acquisition, I.S.T. All authors have read and agreed to the published version of the manuscript.

Funding: This work was funded by the research university grant, GUP-2019-086, from the National University of Malaysia (UKM). This work was also supported by the Centre for Diagnostic, Therapeutic and Investigative Studies (CODTIS), Faculty of Health Sciences, (UKM.). 
Institutional Review Board Statement: Not applicable.

Informed Consent Statement: Not applicable.

Conflicts of Interest: The authors declare no conflict of interest. The funders had no role in the design of the study; in the collection, analyses, or interpretation of data; in the writing of the manuscript, or in the decision to publish the results.

\section{Abbreviations}

$3 \beta$-HSD $\quad 3 \beta$-hydroxysteroid dehydrogenase

$5 \alpha \operatorname{Red} 1 \quad 5 \alpha$-reductase type 1

$17 \beta$-HSD $\quad 17 \beta$-hydroxysteroid dehydrogenase

AA arachidonic acid

AD androstenedione

AR androgen receptor

ATP adenosine 5'-triphosphate

BPA bisphenol A

BPAF bisphenol AF

BPF bisphenol $\mathrm{F}$

BPS bisphenol S

BTB blood-testis-barrier

cAMP cyclic adenosine monophosphate

CatSper sperm-specific ion calcium $\left(\mathrm{Ca}^{2+}\right)$ channel

CYP11A1 cytochrome P450 isoform 1A1

CYP17 cytochrome P450 isoform 17

CYP19A1 cytochrome P450 isoform 19A1

COX-2 cyclooxygenase-2

DHEA dehydroepiandrosterone

E2 estradiol

EDCs endocrine disrupting chemicals

EPA Environmental Protection Agency

ER estrogen receptor

ER $\alpha / \beta \quad$ estrogen receptor $\alpha / \beta$

ERR- $\gamma \quad$ estrogen-related receptor gamma

FSH follicle-stimulating hormone

$\mathrm{FSH} \beta \quad$ follicle-stimulating hormone beta

FT free testosterone

$\mathrm{GnRH} \quad$ gonadotropin-releasing hormone

Gnrh2 gonadotropin-releasing hormone 2

GnRH3 gonadotropin-releasing hormone 3

GnRHR GnRH receptor

GnRHR 1/2 GnRH receptor $1 / 2$

GPR54 G-protein coupled receptor 54

HPG hypothalamic-pituitary-gonadal axis

HSD hydroxysteroid dehydrogenase

INB inhibin B

IVF in vitro fertilization

LC Leydig cells

LH luteinizing hormone

$\mathrm{LH} \beta \quad$ luteinizing hormone beta

LHR luteinizing hormone receptor

MAPK mitogen-activated protein kinase

mFeTA mouse fetal testicular cell assay

mRNA messenger RNA

PGE-2 prostaglandin E2 


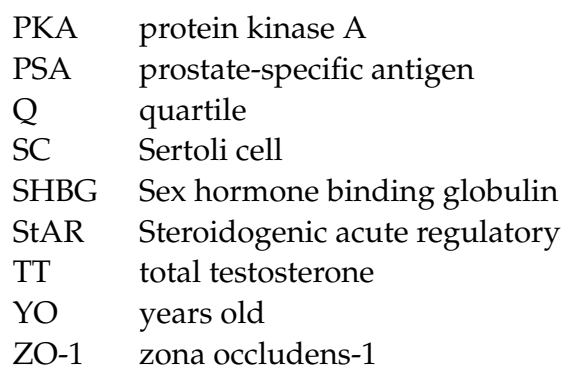

\section{References}

1. Michałowicz, J.; Bisphenol, A. Sources, toxicity and biotransformation. Environ. Toxicol. Pharmacol. 2014, 37, 738-758. [CrossRef]

2. Park, B.; Kwon, J.E.; Cho, S.M.; Kim, C.W.; Lee, D.E.; Koo, Y.T.; Lee, S.H.; Lee, H.M.; Kang, S.C. Protective effect of Lespedeza cuneata ethanol extract on Bisphenol A-induced testicular dysfunction in vivo and in vitro. Biomed. Pharmacother. 2018, 102, 76-85. [CrossRef]

3. Abraham, A.; Chakraborty, P. A review on sources and health impacts of bisphenol A. Rev. Environ. Health 2020, 35, 201-210. [CrossRef]

4. $\quad$ Castillo-Sanchez, R.; Ramirez-Ricardo, J.; Martinez-Baeza, E.; Cortes-Reynosa, P.; Candanedo-Gonzales, F.; Gomez, R.; Salazar, E.P. Bisphenol A induces focal adhesions assembly and activation of FAK, Src and ERK2 via GPER in MDA-MB-231 breast cancer cells. Toxicol. Vitr. 2020, 66, 104871. [CrossRef] [PubMed]

5. Talpade, J.; Shrman, K.; Sharma, R.K.; Gutham, V.; Singh, R.P.; Meena, N.S. Bisphenol A: An endocrine disruptor. J. Entomol. Zool. Stud. 2018, 6, 394-397.

6. Bakar, N.A.; Salleh, M.M.; Umar, A.A.; Shapter, J.G. Design and measurement technique of surface-enhanced Raman scattering for detection of bisphenol A. Adv. Nat. Sci. Nanosci. Nanotechnol. 2017, 8, 025008. [CrossRef]

7. Kang, J.-H.; Kondo, F.; Katayama, Y. Human exposure to Bisphenol A. Toxicology 2006, 226, 79-89. [CrossRef]

8. Kawamura, Y.; Etoh, M.; Hirakawa, Y.; Abe, Y.; Mutsuga, M. Bisphenol A in domestic and imported canned foods in Japan. Food Addit. Contam. Part A Chem. 2014, 31, 330-340. [CrossRef]

9. Pelch, K.; Wignall, J.A.; Goldstone, A.E.; Ross, P.K.; Blain, R.B.; Shapiro, A.J.; Holmgren, S.D.; Hsieh, J.H.; Svoboda, D.; Auerbach, S.S.; et al. A scoping review of the health and toxicological activity of bisphenol A (BPA) structural analogues and functional alternatives. Toxicology 2019, 424, 152235. [CrossRef]

10. Bakirhan, N.K.; Ozkan, S.A. The recent electrochemical studies on bisphenol a detection in beverages. In Safety Issues in Beverage Production; Grumezescu, A.M., Holban, A.M., Eds.; Academic Press: Cambridge, MA, USA, 2019; Volume 18, pp. 309-333. [CrossRef]

11. Bashir, A.B.; Audu, A.A. Determination of Bisphenol A Released From Polycarbonate Infant Feeding Bottles By UV-Vis Spectrophotometry. J. Chem. Soc. Niger. 2020, 45, 1120-1127. [CrossRef]

12. Ugboka, U.G.; Ihedioha, J.N.; Ekere, N.R.; Okechukwu, F.O. Human health risk assessment of bisphenol A released from polycarbonate drinking water bottles and carbonated drinks exposed to sunlight in Nigeria. Int. J. Environ. Anal. Chem. 2020, 1-11. [CrossRef]

13. Wang, R.; Huang, Y.; Dong, S.; Wang, P.; Su, X. The occurrence of bisphenol compounds in animal feed plastic packaging and migration into feed. Chemosphere 2021, 265, 129022. [CrossRef]

14. Lalonde, B.; Garron, C. Spatial and Temporal Distribution of BPA in the Canadian Freshwater Environment. Arch. Environ. Contam. Toxicol. 2020, 78, 568-578. [CrossRef] [PubMed]

15. Liao, C.; Liu, F.; Guo, Y.; Moon, H.B.; Nakata, H.; Wu, Q.; Kannan, K. Occurrence of eight bisphenol analogues in indoor dust from the United States and several Asian countries: Implications for human exposure. Environ. Sci. Technol. 2012, 46, 9138-9145. [CrossRef] [PubMed]

16. Liao, C.; Kannan, K. A survey of bisphenol A and other bisphenol analogues in foodstuffs from nine cities in China. Food Addit. Contam. Part A 2014, 31, 319-329. [CrossRef] [PubMed]

17. Rotimi, O.A.; Olawole, T.D.; De Campos, O.C.; Adelani, I.B.; Rotimi, S.O. Bisphenol A in Africa: A review of environmental and biological levels. Sci. Total Environ. 2021, 764, 142854. [CrossRef]

18. Zhao, X.; Zhang, H.; Chen, Z.-L.; Wang, X.-C.; Shen, J.-M. Spatial and temporal distributions of bisphenol analogues in water and sediment from the Lanzhou section of the Yellow River, China. Arab. J. Geosci. 2020, 13, 1-8. [CrossRef]

19. Derakhshan, A.; Philips, E.M.; Ghassabian, A.; Santos, S.; Asimakopoulos, A.G.; Kannan, K.; Kortenkamp, A.; Jaddoe, V.W.V.; Trasande, L.; Peeters, R.P.; et al. Association of urinary bisphenols during pregnancy with maternal, cord blood and childhood thyroid function. Environ. Int. 2021, 146, 106160. [CrossRef] [PubMed]

20. Jin, H.; Xie, J.; Mao, L.; Zhao, M.; Bai, X.; Wen, J.; Shen, T.; Wu, P. Bisphenol analogue concentrations in human breast milk and their associations with postnatal infant growth. Environ. Pollut. 2020, 259, 113779. [CrossRef]

21. Polydorou, O.; Schmidt, O.C.; Spraul, M.; Vach, K.; Schulz, S.D.; König, A.; Hellwig, E.; Gminski, R. Detection of Bisphenol A in dental wastewater after grinding of dental resin composites. Dent. Mater. 2020, 36, 1009-1018. [CrossRef] 
22. Cao, X.L.; Kosarac, I.; Popovic, S.; Zhou, S.; Smith, D.; Dabeka, R. LC-MS/MS analysis of bisphenol S and five other bisphenols in total diet food samples. Food Addit. Contam Part A 2019, 36, 1740-1747. [CrossRef]

23. Haq, M.E.U.; Akash, M.S.H.; Sabir, S.; Mahmood, M.H.; Rehman, K. Human exposure to bisphenol A through dietary sources and development of diabetes mellitus: A cross-sectional study in Pakistani population. Environ. Sci. Pollut. Res. 2020, 27, 26262-26275. [CrossRef] [PubMed]

24. Malaisé, Y.; Lencina, C.; Cartier, C.; Olier, M.; Ménard, S.; Guzylack-Piriou, L. Perinatal oral exposure to low doses of bisphenol A, S or F impairs immune functions at intestinal and systemic levels in female offspring mice. Environ. Health 2020, 19, 1-11. [CrossRef] [PubMed]

25. Rolfo, A.; Nuzzo, A.M.; De Amicis, R.; Moretti, L.; Bertoli, S.; Leone, A. Fetal-maternal exposure to endocrine disruptors: Correlation with diet intake and pregnancy outcomes. Nutrients 2020, 12, 1744. [CrossRef] [PubMed]

26. Adeyemi, J.A.; Gallimberti, M.; Olise, C.C.; Rocha, B.A.; Adedire, C.O.; Barbosa, F. Evaluation of bisphenol A levels in Nigerian thermal receipts and estimation of daily dermal exposure. Environ. Sci. Pollut. Res. 2020, 27, 37645-37649. [CrossRef] [PubMed]

27. González, N.; Marquès, M.; Cunha, S.C.; Fernandes, J.O.; Domingo, J.L.; Nadal, M. Biomonitoring of co-exposure to bisphenols by consumers of canned foodstuffs. Environ. Int. 2020, 140, 105760. [CrossRef]

28. Sánchez-Piñero, J.; Bowerbank, S.L.; Moreda-Piñeiro, J.; López-Mahía, P.; Dean, J.R. The occurrence and distribution of polycyclic aromatic hydrocarbons, bisphenol A and organophosphate flame retardants in indoor dust and soils from public open spaces: Implications for human exposure. Environ. Pollut. 2020, 266, 115372. [CrossRef]

29. Zhang, H.; Quan, Q.; Zhang, M.; Zhang, N.; Zhang, W.; Zhan, M.; Xu, W.; Lu, L.; Fan, J.; Wang, Q. Occurrence of bisphenol A and its alternatives in paired urine and indoor dust from Chinese university students: Implications for human exposure. Chemosphere 2020, 247, 125987. [CrossRef]

30. Hart, R.J. The Impact of Prenatal Exposure to Bisphenol A on Male Reproductive Function. Front. Endocrinol. 2020, 11, 320. [CrossRef] [PubMed]

31. Meli, R.; Monnolo, A.; Annunziata, C.; Pirozzi, C.; Ferrante, M.C. Oxidative stress and BPA toxicity: An antioxidant approach for male and female reproductive dysfunction. Antioxidants 2020, 9, 405. [CrossRef]

32. Shokry, D.A.; Mohamed, M.I.; Abdel-Satar, M.F.; Selim, N.E.S.; Abd El Salam, M.A. Correlation between urinary bisphenol a (BPA) levels and male reproductive functions among sample of Egyptian population. Indian J. Forensic Med. Toxicol. 2020, 14, 1821-1826. [CrossRef]

33. Aljadeff, G.; Longhi, E.; Shoenfeld, Y. Bisphenol A: A notorious player in the mosaic of autoimmunity. Autoimmunity 2018, 51, 370-377. [CrossRef] [PubMed]

34. Gao, X.; Wang, H.S. Impact of bisphenol A on the cardiovascular system-Epidemiological and experimental evidence and molecular mechanisms. Int. J. Environ. Res. Public Health 2014, 11, 8399-8413. [CrossRef]

35. Kharrazian, D. The potential roles of bisphenol A (BPA) pathogenesis in autoimmunity. Autoimmune Dis. 2014, $2014,743616$. [CrossRef]

36. Nakajima, Y.; Goldblum, R.M.; Midoro-Horiuti, T. Fetal exposure to bisphenol A as a risk factor for the development of childhood asthma: An animal model study. Environ. Health 2012, 11, 8. [CrossRef] [PubMed]

37. Skakkebaek, N.E.; Toppari, J.; Söder, O.; Gordon, C.M.; Divall, S.; Draznin, M. The exposure of fetuses and children to endocrine disrupting chemicals: A European Society for Paediatric Endocrinology (ESPE) and Pediatric Endocrine Society (PES) call to action statement. J. Clin. Endocrinol. Metab. 2011, 96, 3056-3058. [CrossRef]

38. Wang, Z.; Liang, H.; Tu, X.; Yuan, W.; Zhou, Z.; Jin, L.; Miao, M.; Li, D.K. Bisphenol A and pubertal height growth in school-aged children. J. Expo. Sci. Environ. Epidemiol. 2019, 29, 109-117. [CrossRef] [PubMed]

39. Chianese, R.; Troisi, J.; Richards, S.; Scafuro, M.; Fasano, S.; Guida, M.; Pierantoni, R.; Meccariello, R. Bisphenol A in Reproduction: Epigenetic Effects. Curr. Med. Chem. 2018, 25, 748-770. [CrossRef] [PubMed]

40. Lombó, M.; Fernández-Díez, C.; González-Rojo, S.; Herráez, M.P. Genetic and epigenetic alterations induced by bisphenol A exposure during different periods of spermatogenesis: From spermatozoa to the progeny. Sci. Rep. 2019, 9, 18029. [CrossRef]

41. Gys, C.; Bastiaensen, M.; Malarvannan, G.; Ait Bamai, Y.; Araki, A.; Covaci, A. Short-term variability of bisphenols in spot, morning void and 24-hour urine samples. Environ. Pollut. 2021, 268, 115747. [CrossRef]

42. Huang, M.; Liu, S.; Fu, L.; Jiang, X.; Yang, M. Bisphenol A and its analogues bisphenol S, bisphenol F and bisphenol AF induce oxidative stress and biomacromolecular damage in human granulosa KGN cells. Chemosphere 2020, 253, 126707. [CrossRef] [PubMed]

43. Li, A.; Zhuang, T.; Shi, W.; Liang, Y.; Liao, C.; Song, M.; Jiang, G. Serum concentration of bisphenol analogues in pregnant women in China. Sci. Total Environ. 2020, 707, 136100. [CrossRef]

44. Sharma, P.; Gautam, D.K.; Bhagat, P.; Mandal, M.B. Comparative assessment of impact of Bisphenol A and Bisphenol S on hematological parameters in rats after 4 weeks exposure. J. Crit. Rev. 2020, 7, 1250-1256.

45. Andújar, N.; Gálvez-Ontiveros, Y.; Zafra-Gómez, A.; Rodrigo, L.; Álvarez-Cubero, M.J.; Aguilera, M.; Monteagudo, C.; Rivas, A. Bisphenol A analogues in food and their hormonal and obesogenic effects: A review. Nutrients 2019, 11, 2136. [CrossRef]

46. García-Córcoles, M.T.; Cipa, M.; Rodríguez-Gómez, R.; Rivas, A.; Olea-Serrano, F.; Vílchez, J.L.; Zafra-Gómez, A. Determination of bisphenols with estrogenic activity in plastic packaged baby food samples using solid-liquid extraction and clean-up with dispersive sorbents followed by gas chromatography tandem mass spectrometry analysis. Talanta 2018, 178, 441-448. [CrossRef] [PubMed] 
47. Harnett, K.G.; Chin, A.; Schuh, S.M. BPA and BPA alternatives BPS, BPAF, and TMBPF, induce cytotoxicity and apoptosis in rat and human stem cells. Ecotoxicol. Environ. Saf. 2021, 216, 112210. [CrossRef]

48. Environmental Protection Agency (EPA). Bisphenol A Alternatives in Thermal Paper Final Report. Available online: https: / / www.epa.gov/sites/default/files/2015-08/documents/bpa_final.pdf (accessed on 10 June 2021).

49. Jubaidi, F.F.; Mathialagan, R.D.; Noor, M.M.; Taib, I.S.; Budin, S.B. Monosodium glutamate daily oral supplementation: Study of its effects on male reproductive system on rat model. Syst. Biol. Reprod. Med. 2019, 65, 194-204. [CrossRef]

50. Yusoff, N.A.; Mohamed, M.; Budin, S.B.; Taib, I.S. Fenitrothion impaired sexual behaviour and reproductive performance in male sprague-Dawley rats. Sains Malays. 2020, 49, 1333-1344. [CrossRef]

51. Gules, O.; Yildiz, M.; Naseer, Z.; Tatar, M. Effects of folic acid on testicular toxicity induced by bisphenol-A in male Wistar rats. Biotech. Histochem. 2019, 94, 26-35. [CrossRef]

52. Ullah, A.; Pirzada, M.; Jahan, S.; Ullah, H.; Khan, M.J. Bisphenol A analogues bisphenol B, bisphenol F, and bisphenol S induce oxidative stress, disrupt daily sperm production, and damage DNA in rat spermatozoa: A comparative in vitro and in vivo study. Toxicol. Ind. Health 2019, 35, 294-303. [CrossRef]

53. Yusoff, N.A.; Budin, S.B.; Taib, I.S. Pesticide Exposures Induce Male-Mediated Reproductive Toxicity: A Review. J. Agric. Sci. 2017, 9, 122-135. [CrossRef]

54. Rahman, M.S.; Pang, M.G. Understanding the molecular mechanisms of bisphenol A action in spermatozoa. Clin. Exp. Reprod. Med. 2019, 46, 99-106. [CrossRef] [PubMed]

55. Roelofs, M.J.E.; van den Berg, M.; Bovee, T.F.H.; Piersma, A.H.; Duursen, M.B.M. Structural bisphenol analogues differentially target steroidogenesis in murine MA-10 Leydig cells as well as the glucocorticoid receptor. Toxicology 2015, 329, 10-20. [CrossRef]

56. Yang, Q.; Yang, X.; Liu, J.; Ren, W.; Chen, Y.; Shen, S. Effects of BPF on steroid hormone homeostasis and gene expression in the hypothalamic-pituitary-gonadal axis of zebrafish. Environ. Sci. Pollut. Res. 2017, 24, 21311-21322. [CrossRef]

57. Bruks, S. Metabolism and Estrogenicity of Bisphenol A and Its Analogues: A Comparative Analysis of Experimental and Computational Data on Metabolism of Bisphenols. Bachelor's Thesis, Umeå University, Umeå, Sweden, 24 April 2020.

58. Zühlke, M.K.; Schlüter, R.; Mikolasch, A.; Henning, A.K.; Giersberg, M.; Lalk, M.; Kunze, G.; Schweder, T.; Urich, T.; Schauer, F. Biotransformation of bisphenol A analogues by the biphenyl-degrading bacterium Cupriavidus basilensis-A structurebiotransformation relationship. Appl. Microbiol. Biotechnol. 2020, 104, 3569-3583. [CrossRef]

59. Cano-Nicolau, J.; Vaillant, C.; Pellegrini, E.; Charlier, T.D.; Kah, O.; Coumailleau, P. Estrogenic effects of several BPA analogs in the developing zebrafish brain. Front. Neurosci. 2016, 10, 112. [CrossRef] [PubMed]

60. In, S.; Cho, H.; Lee, K.W.; Won, E.J.; Lee, Y.M. Cloning and molecular characterization of estrogen-related receptor (ERR) and vitellogenin genes in the brackish water flea Diaphanosoma celebensis exposed to bisphenol A and its structural analogues. Mar. Pollut. Bull. 2020, 154, 111063. [CrossRef]

61. Lina, S.; Eliza, H.; Hashida, N.H.; Ibrahim, S.F.; Osman, K. Androgen receptor and ultrastructural features of nigella sativa oil and nicotine-treated male rat reproductive glands. Sains Malays. 2018, 47, 1827-1833. [CrossRef]

62. Qiu, W.; Zhao, Y.; Yang, M.; Farajzadeh, M.; Pan, C.; Wayne, N.L. Actions of bisphenol A and bisphenol S on the reproductive neuroendocrine system during early development in zebrafish. Endocrinology 2016, 157, 636-647. [CrossRef]

63. Matuszczak, E.; Komarowska, M.D.; Debek, W.; Hermanowicz, A. The Impact of Bisphenol A on Fertility, Reproductive System, and Development: A Review of the Literature. Int. J. Endocrinol. 2019, 2019, 4068717. [CrossRef] [PubMed]

64. Alboghobeish, S.; Mahdavinia, M.; Zeidooni, L.; Samimi, A.; Oroojan, A.A.; Alizadeh, S.; Dehghani, M.A.; Ahangarpour, A.; Khorsandi, L. Efficiency of naringin against reproductive toxicity and testicular damages induced by bisphenol A in rats. Iran J. Basic Med. Sci. 2019, 22, 315-323. [CrossRef]

65. Jiang, Z.; Wang, J.; Li, X.; Zhang, X. Echinacoside and Cistanche tubulosa (Schenk) R. wight ameliorate bisphenol A-induced testicular and sperm damage in rats through gonad axis regulated steroidogenic enzymes. J. Ethnopharmacol. 2016, 193, 321-328. [CrossRef]

66. Zahra, Z.; Khan, M.R.; Majid, M.; Maryam, S.; Sajid, M. Gonadoprotective ability of Vincetoxicum arnottianum extract against bisphenol A-induced testicular toxicity and hormonal imbalance in male Sprague Dawley rats. Andrologia 2020, 52, e13590. [CrossRef] [PubMed]

67. Wang, J.; Chen, C.; Jiang, Z.; Wang, M.; Jiang, H.; Zhang, X. Protective effect of Cordyceps militaris extract against bisphenol A induced reproductive damage. Syst. Biol. Reprod. Med. 2016, 62, 249-257. [CrossRef]

68. Ullah, A.; Pirzada, M.; Afsar, T.; Razak, S.; Almajwal, A.; Jahan, S. Effect of bisphenol F, an analog of bisphenol A, on the reproductive functions of male rats. Environ. Health Prev. Med. 2019, 24, 41. [CrossRef]

69. Ullah, A.; Pirzada, M.; Jahan, S.; Ullah, H.; Shaheen, G.; Rehman, H.; Siddiqui, M.F.; Butt, M.A. Bisphenol A and its analogs bisphenol B, bisphenol F, and bisphenol S: Comparative in vitro and in vivo studies on the sperms and testicular tissues of rats. Chemosphere 2018, 209, 508-516. [CrossRef] [PubMed]

70. Ullah, H.; Jahan, S.; Ain, Q.U.; Shaheen, G.; Ahsan, N. Effect of bisphenol S exposure on male reproductive system of rats: A histological and biochemical study. Chemosphere 2016, 152, 383-391. [CrossRef]

71. Stoker, C.; Andreoli, M.F.; Kass, L.; Bosquiazzo, V.L.; Rossetti, M.F.; Canesini, G.; Luque, E.H.; Ramos, J.G. Perinatal exposure to bisphenol A (BPA) impairs neuroendocrine mechanisms regulating food intake and kisspetin system in adult male rats. Evidences of metabolic disruptor hypothesis. Mol. Cell. Endocrinol. 2020, 499, 110614. [CrossRef] 
72. Bai, Y.; Chang, F.; Zhou, R.; Jin, P.P.; Matsumoto, H.; Sokabe, M.; Chen, L. Increase of anteroventral periventricular kisspeptin neurons and generation of E2-induced LH-surge system in male rats exposed perinatally to environmental dose of bisphenol-A. Endocrinology 2011, 152, 1562-1571. [CrossRef]

73. Cao, J.; Mickens, J.A.; McCaffrey, K.A.; Leyrer, S.M.; Patisaul, H.B. Neonatal Bisphenol A exposure alters sexually dimorphic gene expression in the postnatal rat hypothalamus. Neurotoxicology 2012, 33, 23-36. [CrossRef] [PubMed]

74. Shi, J.; Jiao, Z.; Zheng, S.; Li, M.; Zhang, J.; Feng, Y.; Yin, J.; Shao, B. Long-term effects of Bisphenol AF (BPAF) on hormonal balance and genes of hypothalamus-pituitary-gonad axis and liver of zebrafish (Danio rerio), and the impact on offspring. Chemosphere 2015, 128, 252-257. [CrossRef]

75. Majid, M.; Ijaz, F.; Baig, M.W.; Nasir, B.; Khan, M.R.; Haq, I.U. Scientific Validation of Ethnomedicinal Use of Ipomoea batatas L. Lam. as Aphrodisiac and Gonadoprotective Agent against Bisphenol A Induced Testicular Toxicity in Male Sprague Dawley Rats. Biomed. Res. Int. 2019, 2019, 8939854. [CrossRef] [PubMed]

76. Wisniewski, P.; Romano, R.M.; Kizys, M.M.L.; Oliveira, K.C.; Kasamatsu, T.; Giannocco, G.; Chiamolera, M.I.; Dias-da-Silva, M.R.; Romano, M.A. Adult exposure to bisphenol A (BPA) in Wistar rats reduces sperm quality with disruption of the hypothalamicpituitary-testicular axis. Toxicology 2015, 329, 1-9. [CrossRef] [PubMed]

77. Akintunde, J.K.; Farouk, A.A.; Mogbojuri, O. Metabolic treatment of syndrome linked with Parkinson's disease and hypothalamus pituitary gonadal hormones by turmeric curcumin in Bisphenol-A induced neuro-testicular dysfunction of wistar rat. Biochem. Biophys. Rep. 2019, 17, 97-107. [CrossRef] [PubMed]

78. Eladak, S.; Grisin, T.; Moison, D.; Guerquin, M.J.; N’Tumba-Byn, T.; Pozzi-Gaudin, S.; Benachi, A.; Livera, G.; Rouiller-Fabre, V.; Habert, R. A new chapter in the bisphenol a story: Bisphenol $\mathrm{S}$ and bisphenol $\mathrm{F}$ are not safe alternatives to this compound. Fertil. Steril. 2015, 103, 11-21. [CrossRef]

79. Feng, Y.; Jiao, Z.; Shi, J.; Li, M.; Guo, Q.; Shao, B. Effects of bisphenol analogues on steroidogenic gene expression and hormone synthesis in H295R cells. Chemosphere 2016, 147, 9-19. [CrossRef]

80. Jahan, S.; Ain, Q.U.; Ullah, H. Therapeutic effects of quercetin against bisphenol A induced testicular damage in male Sprague Dawley rats. Syst. Biol. Reprod. Med. 2016, 62, 114-124. [CrossRef]

81. Liang, S.; Yin, L.; Yu, K.S.; Hofmann, M.C.; Yu, X. High-content analysis provides mechanistic insights into the testicular toxicity of Bisphenol A and selected analogues in mouse spermatogonial cells. Toxicol. Sci. 2017, 155, 43-60. [CrossRef]

82. de Freitas, A.T.A.G.; Ribeiro, M.A.; Pinho, C.F.; Peixoto, A.R.; Domeniconi, R.F.; Scarano, W.R. Regulatory and junctional proteins of the blood-testis barrier in human Sertoli cells are modified by monobutyl phthalate (MBP) and bisphenol A (BPA) exposure. Toxicol. Vitr. 2016, 34, 1-7. [CrossRef] [PubMed]

83. Feng, Y.-L.; Yin, Y.-Y.; Wang, X.-S.; Wang, P.-T. BPA Disturb TJ-Permeability of Rat Sertoli Cells During Spermatogenesis in Vitro. Prog. Mod. Biomed. 2012, 12, 1430-1434.

84. Wang, H.F.; Liu, M.; Li, N.; Luo, T.; Zheng, L.P.; Zeng, X.H. Bisphenol a impairs mature sperm functions by a CatSper-relevant mechanism. Toxicol. Sci. 2016, 152, 145-154. [CrossRef]

85. Rehfeld, A.; Andersson, A.M.; Skakkebæk, N.E. Bisphenol A Diglycidyl Ether (BADGE) and Bisphenol Analogs, but Not Bisphenol A (BPA), Activate the CatSper $\mathrm{Ca}^{2+}$ Channel in Human Sperm. Front. Endocrinol. 2020, 11, 324. [CrossRef]

86. Zhu, N.; Zhao, M.; Song, Y.; Ding, L.; Ni, Y. The KiSS-1/GPR54 system: Essential roles in physiological homeostasis and cancer biology. Genes Dis. 2020, in press. [CrossRef]

87. Dedes, I. Kisspeptins and the control of gonadotrophin secretion. Syst. Biol. Reprod. Med. 2012, 58, 121-128. [CrossRef] [PubMed]

88. Khbouz, B.; de Bournonville, C.; Court, L.; Taziaux, M.; Corona, R.; Arnal, J.F.; Lenfant, F.; Cornil, C.A. Role for the membrane estrogen receptor alpha in the sexual differentiation of the brain. Eur. J. Neurosci. 2020, 52, 2627-2645. [CrossRef]

89. Weiser, M.J.; Foradori, C.D.; Handa, R.J. Estrogen receptor beta in the brain: From form to function. Brain Res. Rev. 2008, 57, 309-320. [CrossRef] [PubMed]

90. Chimento, A.; Sirianni, R.; Casaburi, I.; Pezzi, V. Role of estrogen receptors and G protein-coupled estrogen receptor in regulation of hypothalamus-pituitary-testis axis and spermatogenesis. Front. Endocrinol. 2014, 5, 1. [CrossRef]

91. Yeo, S.H.; Colledge, W.H. The role of Kiss1 neurons as integrators of endocrine, metabolic, and environmental factors in the hypothalamic-pituitary-gonadal axis. Front. Endocrinol. 2018, 9, 188. [CrossRef]

92. Zhao, Y.; Lin, M.-C.A.; Farajzadeh, M.; Wayne, N.L. Early Development of the Gonadotropin-Releasing Hormone Neuronal Network in Transgenic Zebrafish. Front. Endocrinol. 2013, 4, 107. [CrossRef] [PubMed]

93. Zirkin, B.R.; Papadopoulos, V. Leydig cells: Formation, function, and regulation. Biol. Reprod. 2018, 99, 101-111. [CrossRef] [PubMed]

94. Flück, C.E.; Pandey, A.V. Testicular Steroidogenesis. In Endocrinology of the Testis and Male Reproduction, 1st ed.; Simoni, M., Huhtaniemi, I., Eds.; Springer: Cham, Switzerland, 2017; pp. 343-371. [CrossRef]

95. Wang, Y.; Chen, F.; Ye, L.; Zirkin, B.; Chen, H. Steroidogenesis in leydig cells: Effects of aging and environmental factors. Reproduction 2017, 154, R111-R122. [CrossRef]

96. Jefcoate, C.R.; Lee, J. Cholesterol signaling in single cells: Lessons from STAR and sm-FISH. J. Mol. Endocrinol. 2018, 60, R213-R235. [CrossRef] [PubMed]

97. Papadopoulos, V.; Aghazadeh, Y.; Fan, J.; Campioli, E.; Zirkin, B.; Midzak, A. Translocator protein-mediated pharmacology of cholesterol transport and steroidogenesis. Mol. Cell. Endocrinol. 2015, 408, 90-98. [CrossRef] 
98. Ronco, A.M.; Moraga, P.F.; Llanos, M.N. Arachidonic acid release from rat Leydig cells: The involvement of G protein, phospholipase A2 and regulation of cAMP production. J. Endocrinol. 2002, 172, 95-104. [CrossRef]

99. Hadley, K.B.; Ryan, A.S.; Forsyth, S.; Gautier, S.; Salem, N. The essentiality of arachidonic acid in infant development. Nutrients 2016, 8, 216. [CrossRef] [PubMed]

100. Rouzer, C.A.; Marnett, L.J. Cyclooxygenases: Structural and functional insights. J. Lipid Res. 2009, 50, S29-S34. [CrossRef] [PubMed]

101. Perrotta, I.; Santoro, M.; Guido, C.; Avena, P.; Tripepi, S.; De Amicis, F.; Gervasi, M.C.; Aquila, S. Expression of cyclooxygenase-1 (COX-1) and COX-2 in human male gametes from normal patients, and those with varicocele and diabetes: A potential molecular marker for diagnosing male infertility disorders. J. Anat. 2012, 221, 209-220. [CrossRef]

102. Wang, X.; Dyson, M.T.; Jo, Y.; Stocco, D.M. Inhibition of cyclooxygenase-2 activity enhances steroidogenesis and steroidogenic acute regulatory gene expression in MA-10 mouse Leydig cells. Endocrinology 2003, 144, 3368-3375. [CrossRef] [PubMed]

103. Scott, H.M.; Mason, J.I.; Sharpe, R.M. Steroidogenesis in the fetal testis and its susceptibility to disruption by exogenous compounds. Endocr. Rev. 2009, 30, 883-925. [CrossRef]

104. Xiao, X.; Mruk, D.D.; Wong, C.K.C.; Yan Cheng, C. Germ cell transport across the seminiferous epithelium during spermatogenesis. Physiology 2014, 29, 286-298. [CrossRef]

105. Li, M.W.M.; Mruk, D.D.; Lee, W.M.; Cheng, C.Y. Disruption of the blood-testis barrier integrity by bisphenol A in vitro: Is this a suitable model for studying blood-testis barrier dynamics? Int. J. Biochem. Cell Biol. 2009, 41, 2302-2314. [CrossRef]

106. Kamaruzaman, K.A.; Mat Noor, M. Reversible spermatoxic effect of Andrographis paniculata methanol extract in Sprague Dawley rats. Malays. Appl. Biol. 2012, 46, 225-232.

107. Sun, H.X.; Zhu, Y.; Wang, L.; Ling Liu, H.; Ling, Y.; Li, Z.L.; Sun, L.B. The Catsper channel and its roles in male fertility: A systematic review. Reprod. Biol. Endocrinol. 2017, 15, 65. [CrossRef]

108. Scinicariello, F; Buser, M.C. Serum testosterone concentrations and urinary bisphenol a, benzophenone-3, triclosan, and paraben levels in male and female children and adolescents: NHANES 2011-2012. Environ. Health Perspect. 2016, 124, 1898-1904. [CrossRef] [PubMed]

109. Liu, X.; Miao, M.; Zhou, Z.; Gao, E.; Chen, J.; Wang, J.; Sun, F.; Yuan, W.; Li, D.K. Exposure to bisphenol-A and reproductive hormones among male adults. Environ. Toxicol. Pharmacol. 2015, 39, 934-941. [CrossRef] [PubMed]

110. Zhuang, W.; Wu, K.; Wang, Y.; Zhu, H.; Deng, Z.; Peng, L.; Zhu, G. Association of Serum Bisphenol-A Concentration and Male Reproductive Function among Exposed Workers. Arch. Environ. Contam. Toxicol. 2015, 68, 38-45. [CrossRef]

111. Lassen, T.H.; Frederiksen, H.; Jensen, T.K.; Petersen, J.H.; Joensen, U.N.; Main, K.M.; Skakkebaek, N.E.; Juul, A.; Jørgensen, N.; Andersson, A.M. Urinary bisphenol a level in young men: Association with reproductive hormones and semen quality. Environ. Health Perspect. 2014, 122, 478-484. [CrossRef]

112. Adoamnei, E.; Mendiola, J.; Vela-Soria, F.; Fernández, M.F.; Olea, N.; Jørgensen, N.; Swan, S.H.; Torres-Cantero, A.M. Urinary bisphenol A concentrations are associated with reproductive parameters in young men. Environ. Res. 2018, 161, 122-128. [CrossRef]

113. Taylor, J.A.; Richter, C.A.; Ruhlen, R.L.; Vom Saal, F.S. Estrogenic environmental chemicals and drugs: Mechanisms for effects on the developing male urogenital system. J. Steroid Biochem. Mol. Biol. 2011, 127, 83-95. [CrossRef]

114. Ferguson, K.K.; Peterson, K.E.; Lee, J.M.; Mercado-García, A.; Blank-Goldenberg, C.; Téllez-Rojo, M.M.; Meeker, J.D. Prenatal and peripubertal phthalates and bisphenol A in relation to sex hormones and puberty in boys. Reprod. Toxicol. 2014, 47, 70-76. [CrossRef]

115. Hart, R.J.; Doherty, D.A.; Keelan, J.A.; Minaee, N.S.; Thorstensen, E.B.; Dickinson, J.E.; Pennell, C.E.; Newnham, J.P.; McLachlan, R.; Norman, R.J.; et al. The impact of antenatal Bisphenol A exposure on male reproductive function at 20-22 years of age. Reprod. Biomed. Online 2018, 36, 340-347. [CrossRef] [PubMed]

116. Knez, J.; Kranvogl, R.; Breznik, B.P.; Vončina, E.; Vlaisavljević, V. Are urinary bisphenol A levels in men related to semen quality and embryo development after medically assisted reproduction? Fertil. Steril. 2014, 101, 215-221.e5. [CrossRef]

117. Ghayda, R.A.; Williams, P.L.; Chavarro, J.E.; Ford, J.B.; Souter, I.; Calafat, A.M.; Hauser, R.; Mínguez-Alarcón, L. Urinary bisphenol $\mathrm{S}$ concentrations: Potential predictors of and associations with semen quality parameters among men attending a fertility center. Environ. Int. 2019, 131, 105050. [CrossRef] [PubMed]

118. Goldstone, A.E.; Chen, Z.; Perry, M.J.; Kannan, K.; Louis, G.M.B. Urinary bisphenol A and semen quality, the LIFE study. Reprod. Toxicol. 2015, 51, 7-13. [CrossRef] [PubMed]

119. Benson, T.E.; Gaml-Sørensen, A.; Ernst, A.; Brix, N.; Hougaard, K.S.; Hærvig, K.K.; Ellekilde Bonde, J.P.; Tøttenborg, S.S.; Lindh, C.H.; Ramlau-Hansen, C.H.; et al. Urinary Bisphenol A, F and S Levels and Semen Quality in Young Adult Danish Men. Int. J. Environ. Res. Public Health 2021, 8, 1742. [CrossRef] [PubMed] 